\title{
Typical and atypical stem cells in the brain, vitamin C effect and neuropathology
}

\author{
Francisco Nualart ${ }^{1}{ }^{*}$, Katterine Salazar $^{1}$, Karina Oyarce ${ }^{1}$, Pedro Cisternas ${ }^{1}$, Nery Jara ${ }^{1}$, Carmen Silva-Álvarez ${ }^{1}$, \\ Patricia Pastor ${ }^{1}$, Fernando Martínez ${ }^{2}$, Andrea García ${ }^{1}$, María de los Ángeles García-Robles ${ }^{2}$ and Juan Carlos \\ Tapia $^{3}$
}

${ }^{1}$ Laboratory of Neurobiology and Stem Cells, Center for Advanced Microscopy, CMA Bio Bio, University of Concepción, Concepción, Chile

2 Laboratory of Cellular Biology, Department of Cellular Biology, University of Concepción, Chile

${ }^{3}$ Departments of Neuroscience, Columbia University, New York, USA

\begin{abstract}
Stem cells are considered a valuable cellular resource for tissue replacement therapies in most brain disorders. Stem cells have the ability to self-replicate and differentiate into numerous cell types, including neurons, oligodendrocytes and astrocytes. As a result, stem cells have been considered the "holy grail" of modern medical neuroscience. Despite their tremendous therapeutic potential, little is known about the mechanisms that regulate their differentiation. In this review, we analyze stem cells in embryonic and adult brains, and illustrate the differentiation pathways that give origin to most brain cells. We also evaluate the emergent role of the well known anti-oxidant, vitamin $\mathrm{C}$, in stem cell differentiation. We believe that a complete understanding of all molecular players, including vitamin $\mathrm{C}$, in stem cell differentiation will positively impact on the use of stem cell transplantation for neurodegenerative diseases.
\end{abstract}

Key words: Stem cells, radial glia, vitamin C, SVCT2, brain development, tanycytes, Bergmann glia, neurogenic niche, type B cells, neuroblast, Parkinson's disease, Alzheimer's disease, Amyotrophic lateral sclerosis.

\section{STEM CELLS DURING BRAIN DEVELOPMENT AND ADULT LIFE}

Early during embryogenesis, a layer of neuroepithelial cell folds and fuses to form the neural tube, a well characterized anatomical structure that gives rise to most brain regions (Geelen and Langman, 1979; Ray and Niswander, 2012). Thus, neuroepithelial cells are the primordial neural stem cells of the embryonic brain. These cells have three distinguishable features: i) highly polarized, they face both the ventricular zone (VZ) and the pial surface (Huttner and Brand, 1997); ii) expression of the intermediate filament, nestin (Lendahl et al., 1990); and iii) ability to undergo inter-kinetic nuclear migration, a phenomenon involved in the determination of neural progenitors (Del Bene et al., 2008; Taverna and Huttner, 2010).

In the neural tube, neuroepithelial cells are capable of proliferating actively and symmetrically to increase their population (Egger et al., 2011; Tawk et al., 2007). As development continues, these cells begin to experience asymmetrical divisions, which lead to the generation of the first neuroblasts and basal progenitors, initiating the embryonic neurogenesis process (Haubensak et al., 2004; Kriegstein and Alvarez-Buylla, 2009). Following the onset of neurogenesis, at embryonic days 9-10 in mice (E09-E10), neuroepithelial cells experience several molecular and morphological changes that transform them into a new type of cell, the radial glia. These new progenitor cells uniformly extend a long radial process from the cell body, located at the $\mathrm{VZ}$, all the way to the most external portion of the cortex, the pial surface (Gotz and Huttner, 2005; Morrens et al., 2012;
Yamasaki et al., 2001). Such morphological changes coincide with the expression of different markers, including GLutamate ASpartate Transporter (GLAST), Brain Lipid-Binding Protein (BLBP), Tenascin-C and Glial Fibrillary Acidic Protein (GFAP), which is absent in rodents (Anthony et al., 2004; Hartfuss et al., 2001; Malatesta et al., 2003). Some proteins are highly enriched in radial glial cells. For example, Radial Glia 1 and 2 (RC1 and RC2) are two proteins specific to these cells alone (Edwards et al., 1990). The protein 3-phosphoglycerate dehydrogenase (3-PGDH), a key enzyme for L-serine biosynthesis, is also characteristically expressed in radial glia (Yamasaki et al., 2001). Using immunohistochemical methods, we show the presence of 3-PGDH, in radial glial cells of both E15 embryonic mouse cortex and human cortex at 9 weeks gestation (Figure $1 \mathrm{~A}, \mathrm{~B})$.

Through continuous asymmetrical divisions, radial glial cells give rise to intermediate precursors and neuroblasts (Malatesta et al., 2000) that will then generate most neuronal classes (e.g., pyramidal, stellate, etc). Soon thereafter, these radial glia derived-newborn neurons will use the same radial glial processes as scaffolds to migrate to the appropriate cortical layers (Noctor et al., 2002) (Figure 1C).

Close to the perinatal period, radial glial cells stop producing neurons and differentiate into astrocytes (Culican et al., 1990). In the presence of appropriate trophic factors, radial glial cells in culture differentiate into neuronal and glial cells (Liu and Lauder, 1992; Yamasaki et al., 2001). Interestingly, the number of each differentiated cell type (neuron or glia) depends on the time at which radial glial cells are isolated for the in vitro studies. For example, neuronal formation is favored by radial glia obtained between embryonic days 13- 
16 (E13-E16) while glia generation is promoted by radial glial taken at later stages (embryonic day 18 to postnatal days) (Malatesta et al., 2000; Temple, 2001).

Between postnatal days 1-15 (PN1-PN15), most radial glial cells disappear from almost all brain regions (Tramontin et al., 2003). Radial glia-like cells are however maintained in specific regions of the brain. For instance, the Bergmann glia is a radial glia-like cell that is predominant in cerebellar cortex.
These cells like radial glia present high levels of GFAP and S100 protein expression (Figure 2A-D), generate neuronal and glial progenitors and participate in the migration of newborn granule cells. Such neurogenic activity disappears at later stages of postnatal development. Tanycytes represent another radial glial cell in the hypothalamus (Figure 2E-G). Unlike most radial glial cells, tanycytes maintain their neurogenic activity even in the adult brain (Cifuentes et al., 2011; Lee et

\begin{tabular}{|c|c|}
\hline Mouse brain E15 & Anti-3PGDH + Propidium iodide \\
\hline
\end{tabular}
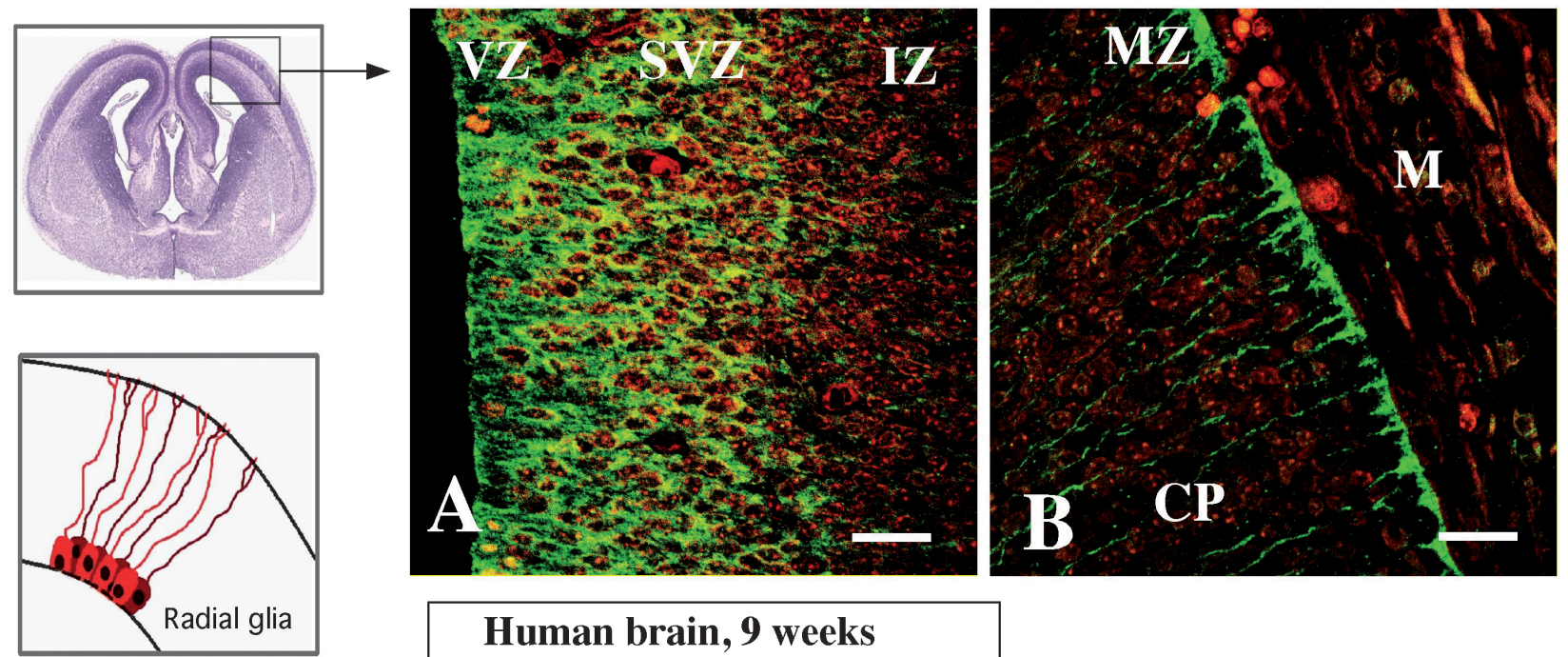

Human brain, 9 weeks

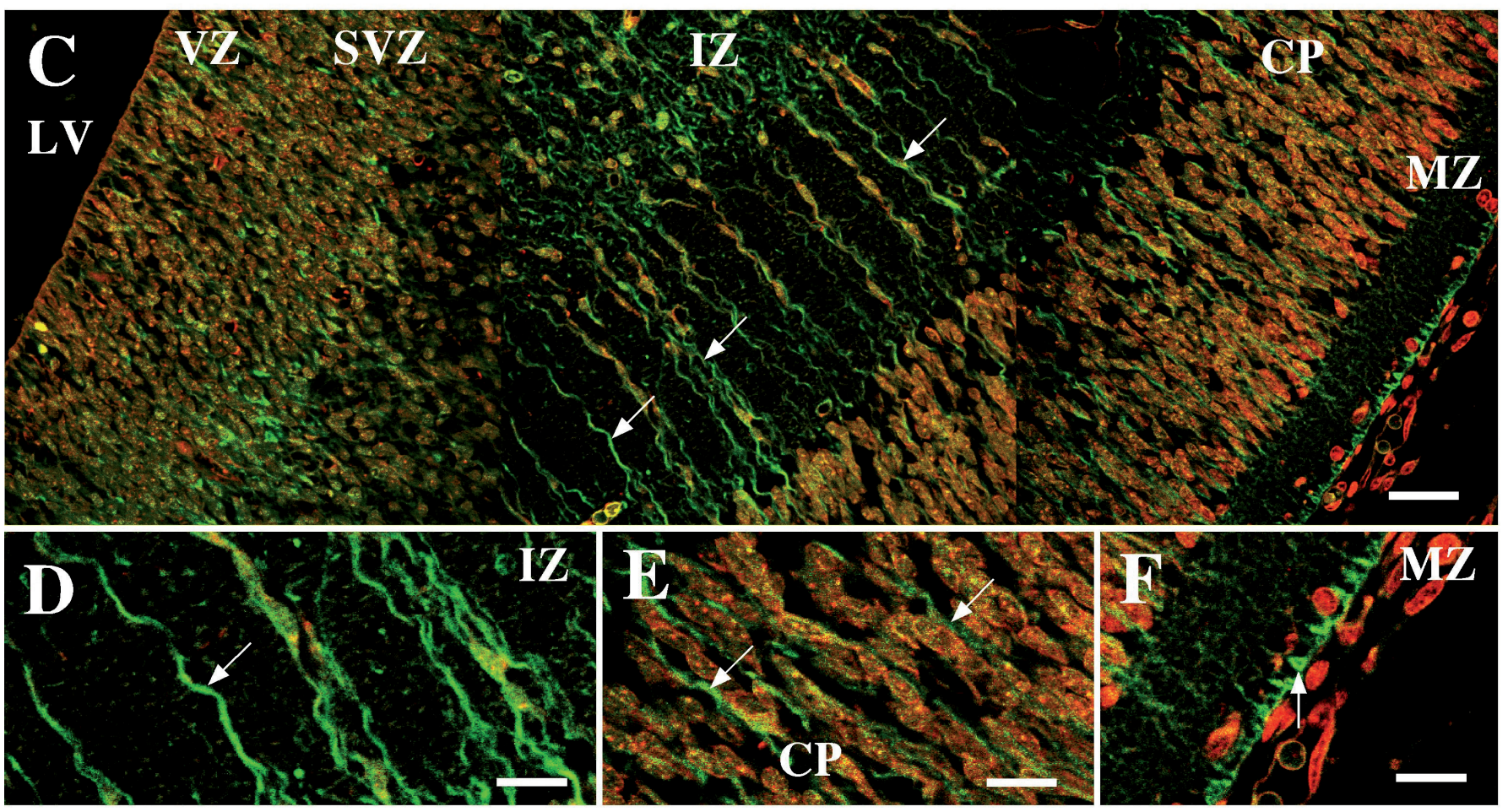

Figure 1. Typical stem cells during embryonic development, Radial glia cells and 3-PGDH expression in mouse and human embryonic brain: (A-B) Embryonic mouse frontal sections immunostained using a specific antibody anti-3-PGDH and a Cy2-labeled secondary antibody. Propidium iodide was used for nuclear staining. (C-D) Similar analyses were performed in sagittal sections of human embryonic brain at 9-weeks of development. A positive reaction in radial glia cells present in the ventricular zone (VZ) and subventricular zone (ZVS) of the mouse and human embryonic cortex was observed. The radial glial processes and end-terminal on meninges (M) were also positive (B and D-F, arrows). CP, cortical plate. IZ, intermediate zone. LV, lateral ventricle. MZ, marginal zone. Scale bars: $15 \mu \mathrm{m}$. 
al., 2012), the reason by which they are considered atypical stem cells. Tanycytes play a major role in the formation of the median eminence-cerebrospinal fluid barrier (Figure 2E). More recently, these cells have been found to be crucial for the brain glucose sensing mechanism (Cortes-Campos et al., 2011; Orellana et al., 2012).

Perhaps the most active neurogenic site present in the mature brain is concentrated in the ventricular wall of lateral ventricle. These radial glial-like stem cells or Type B cells show intense expression of GFAP (Figure 3A-D), maintaining long basal processes in contact with blood vessels (Figure 3E) like radial glial cells. Type B cells are close to ependymal cells, which produce factors that regulate neuronal production; they generate Type C cells, which then proliferate to form Type A cells or neuroblasts (Alvarez-Buylla et al., 1998; Doetsch et al., 1997; Garcia-Verdugo et al., 1998) (Figure 3A). Different studies have shown that the structure of these neurogenic sites is variable across species. For example, in guinea pig brain, we observed an ependymal cell layer positive for Isolectin B4 expression within the subventricular zone (Figure 3F, arrows). Additionally, in the subventricular zone it is possible to find a ribbon of Type B cells (Figure 3F). A similar cellular

\section{Cerebellar cortex, Bergmann glia}
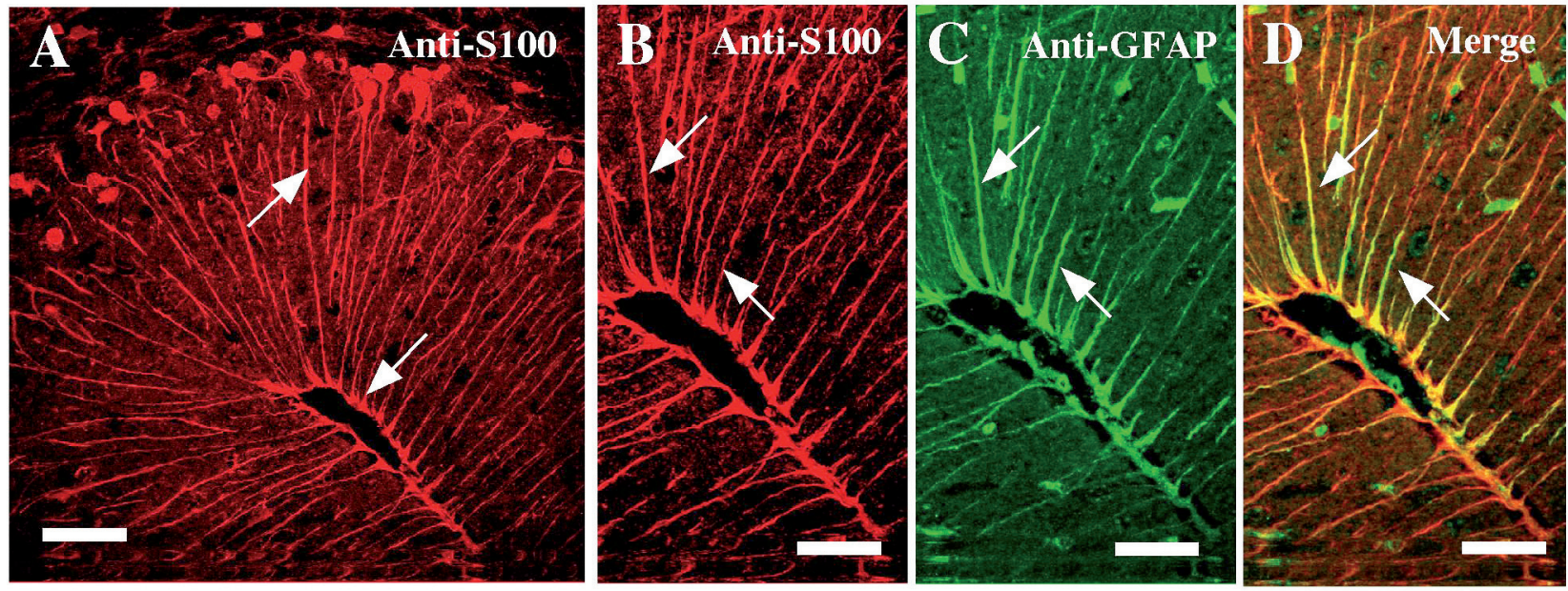

\section{Hypothalamus, median eminence's tanycytes}
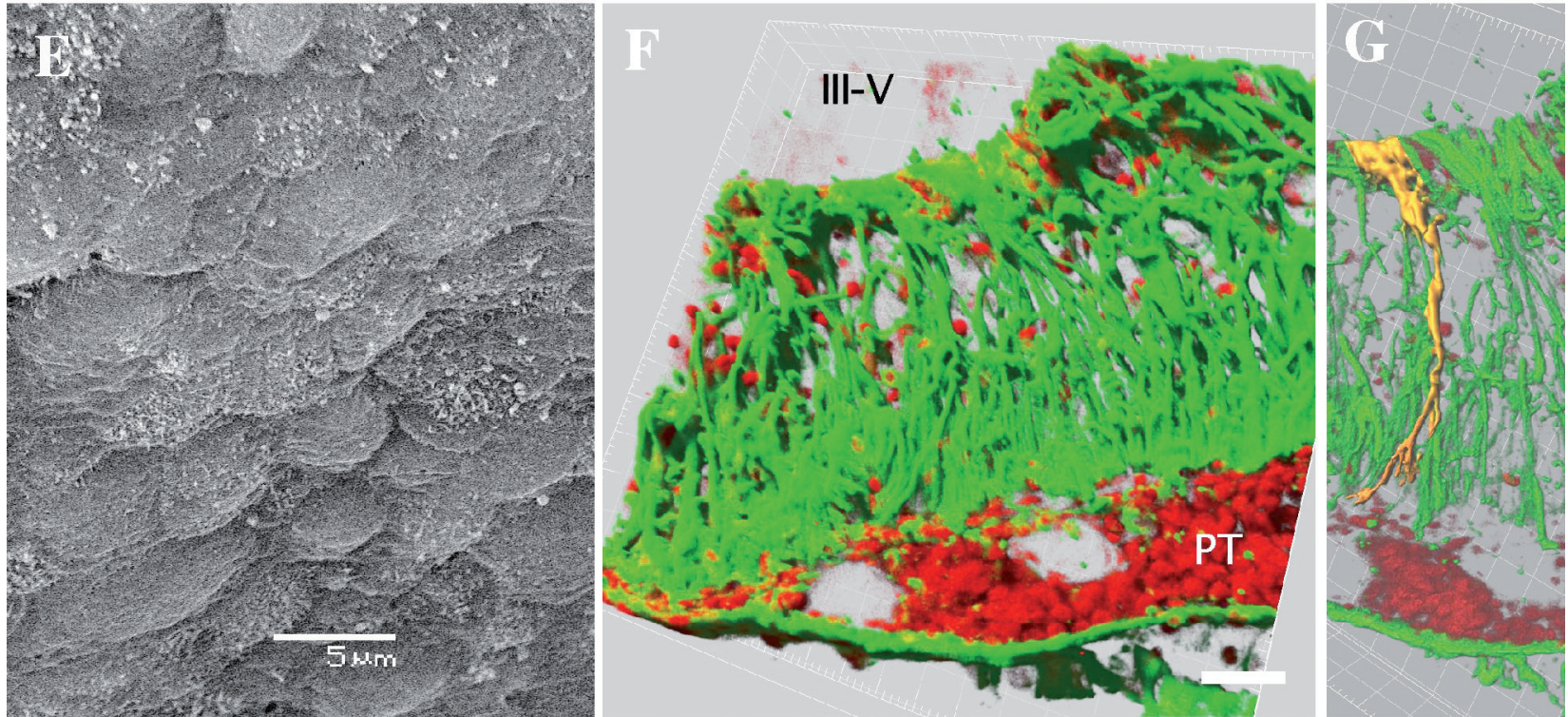

Figure 2. Atypical stem cells during post-natal and adult life, cerebellar Bergmann glia and hypothalamic tanycytes: (A-D) Post-natal cerebellar frontal section of mouse brain immunostained using specific antibodies anti-GFAP or anti-S100, and two different secondary antibodies labeled with Cy2 or Cy3, respectively. The Bergmann glial process and the end-terminal on meninges (A, arrow) were positive (B-D, arrows). (E-G) Tanycytes from the median eminence analyzed using scanning electron microscopy on the ventricular surface, showing the cerebrospinal fluid-median eminence barrier. The processes of these cells are detected using anti-vimentin and a Cy2-labeled secondary antibody. Propidium iodide was used for nuclear staining. The image was processed using the software Imaris. One tanycyte is depicted in yellow in G. III-V, third ventricle. PT, pars tuberalis. Scale bars: $20 \mu \mathrm{m}$. 
organization is observed in the subventricular zone of the human brain (Sanai et al., 2004). In these niches the neuroblasts migrate between Type B and ependymal cells (Figure 3H-I, arrows). Therefore, neurogenic niches seem to present different structures depending on the species studied (Chojnacki et al., 2009).

\section{STEM CELL DIFFERENTIATION: CELLULAR SIGNALING}

How do radial glial cells regulate their fate to first generate neurons and then astrocytes? Experimental evidence suggests that both internal and external signals trigger neurogenesis and gliogenesis (Behar et al., 1994; Colombo et al., 1993; Jiang et al., 1998; Liu and Lauder, 1992; Yamasaki et al., 2001). Once these signals become available in quantities above the activation threshold, radial glial cells respond by differentiating towards a defined cell type. Along with these signals, different genetic programs are activated, allowing radial glial cells to express receptors and proteins necessary to respond specifically to the external stimuli (Ciccolini, 2001; Okano and Temple, 2009; Qian et al., 2000). Of the signals that promote neuronal differentiation, the helix-loop-helix type transcription factors, neurogenin 1 and 2 (Ngn1 and Ngn2); (Guillemot et al., 1993; Ma et al., 1996; Ma et al., 1998; Sommer et al., 1996), Mash1 (Guillemot et al., 1993; Nieto et al., 2001), Math (Gradwohl et al., 1996; Kageyama et al., 2005) and NeuroD (von Bohlen und Halbach, 2011), are among the most well-studied. Ngn1 is a factor primarily expressed during the neurogenic period

\section{Mouse Neurogenic niche, lateral ventricle}
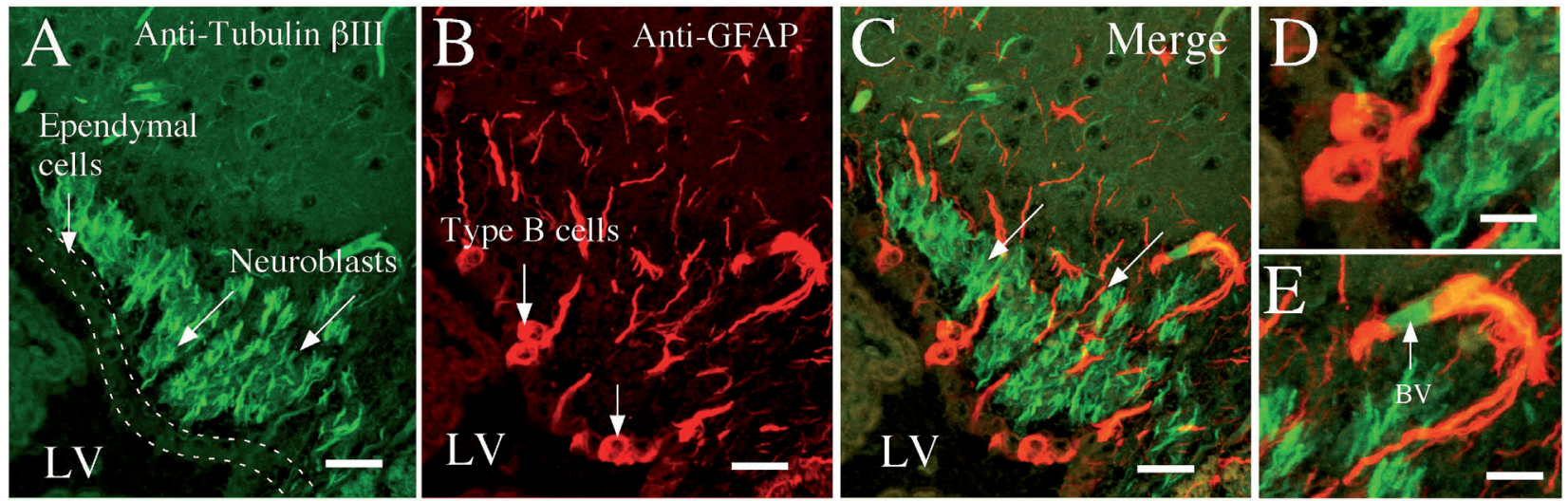

Guinea Pig Neurogenic niche, lateral ventricle
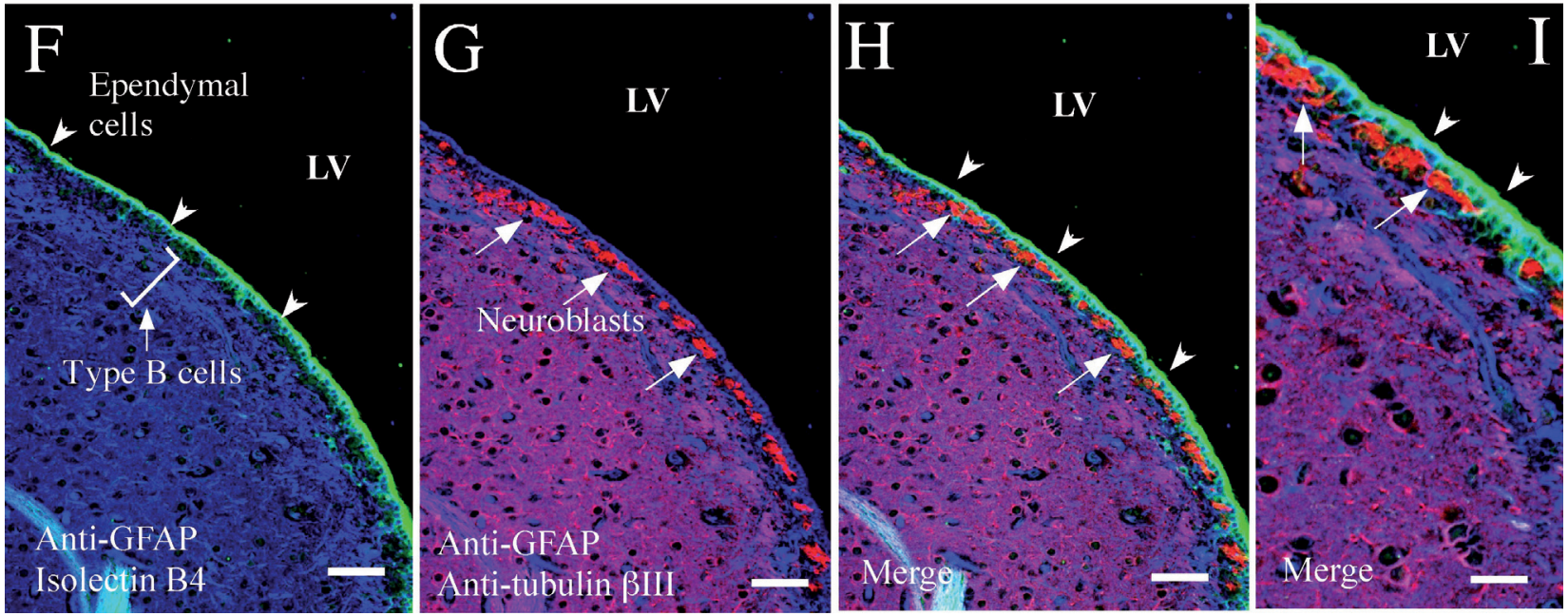

Figure 3. Comparative cellular distribution of typical stem cells present in the adult neurogenic niche of mouse and guinea pig brain: (A-E) Adult mouse frontal brain section of the lateral ventricle neurogenic area immunostained using antibodies specific for anti-tubulin $\beta$ III (neuroblasts marker) or anti-GFAP (type B cells marker), and two different secondary antibodies labeled with Cy2 or Cy3, respectively. The neuroblasts are observed inside the subventricular zone near to the ependymal cells, type $E$ cells (A). Type $B$ cells are detected (GFAP-positive) in the ventricular and subventricular zone close to ependymal cells (B and D). The processes were in contact with the blood vessel of the subventricular zone (E). (F-I) Adult guinea pig frontal brain section of the lateral ventricle neurogenic area immunostained using specific antibodies anti-tubulin $\beta$ III (red) or anti-GFAP (blue), and two different secondary antibodies labeled with Cy3 or Cy5, respectively. The ependymal cells were observed by using Isolectin B4-FITC labeled (green, arrowheads). The astrocytes or Type $B$ cells form a ribbon in the subventricular zone (F). The neuroblasts are detected near the ependymal cells (G-H, arrows). The neurogenic niche structure observed in guinea pig $(\mathrm{I})$ is similar to the neurogenic niche previously described in adult human brain. Bv, blood vessels; LV, lateral ventricle. Scale bars: $20 \mu \mathrm{m}$. 
in the cortex (Fode et al., 2000). Because it induces neuronal differentiation but also inhibits glial differentiation by interfering with the glial signaling pathway JAK/STAT (Sun et al., 2001), it is recognized as a factor capable of modifying neural stem cell fate. Ngn2 is primarily a neurogenic factor expressed in a small population of neural stem cells, and cells that lack Ngn2 requires the presence of Mash1 to generate neurons (Nieto et al., 2001).

Little is known about the extracellular factors that regulate neurogenesis. Recent work indicates that sonic hedgehog (Shh) regulates neurogenesis by directly modulating Ngn1 expression (Ota and Ito, 2003). Neurotrophin 3 (NT3), a factor expressed in the ventricular zone, has also been implicated in neurogenesis (Ohtsuka et al., 2009). Once NT3 is released to the extracellular medium, it activates the ERK1/2 signaling pathway, which ultimately leads to the activation of transcription factors that control neuronal differentiation (Bartkowska et al., 2010; Ohtsuka et al., 2009).

Several factors are known to induce gliogenesis. For example, Notch1 is a membrane receptor expressed in most neural stem cells that upon activation by its Jagged or Delta ligands (Zhou et al., 2010) leads to a cascade of proteolytic events, which culminates with the translocation of its internal domain to the nucleus. In the nucleus, Notch1 acts as a transcriptional transactivator (Morrison et al., 2000; Zhou et al., 2010), inducing demethylation of the binding sites for STAT proteins, such as the promoter of the GFAP and S100B gene. This allows radial glial cells to respond to the JAK/ STAT signaling cascade, a well established gliogenic pathway (Freeman, 2010). Factors, such as ciliary neurotrophic factor (CNTF), leukemia inhibitory factor (LIF) and cardiotrophin 1 (CT1), also regulate gliogenesis. After binding to their respective receptors, each factor activates the JAK/STAT signaling cascade that leads to GFAP expression, a well known marker for glia (Barnabe-Heider et al., 2005; Bhattacharya et al., 2008; Bonni et al., 1997).

Growth factors, such as basic fibroblast growth factor (bFGF) and epidermal growth factor (EGF), are widely used to maintain stem cells in culture; they also participate in stem cell differentiation (Chojnacki et al., 2009). At the onset of neural development, receptors for bFGF are highly enriched in radial glial like stem cells. Interestingly, a large fraction of these receptors are associated with a variety of proteoglycans present in the extracellular matrix (Thisse and Thisse, 2005). Mechanistically, the receptors may uptake the bFGF from the extracellular matrix (Aigner et al., 2002), and upon activation, collaborate in the determination of astrocytic lineage. At present, it is necessary to understand the dynamical relationships between extracellular signals and transcriptional factors. For example, in high concentrations of Ngn1, BMP2 promotes neuronal differentiation. On the contrary, if Ngn1 levels fall, BMP2 promotes gliogenesis (Nakashima et al., 2001). Therefore, studying the different combinations that occur over time might provide insights into the patterns of cellular differentiation.

\section{ROLE OF VITAMIN C IN NEURAL STEM CELL DIFFERENTIA- TION}

Over the years, we have biochemically characterized vitamin C function in brain tissue. Known as a critical antioxidant, recent results suggest that vitamin $C$ plays an important role in stem cell physiology. To gain a deeper understanding into this novel role, we have critically revised the role of vitamin $C$ in stem cell generation, proliferation and differentiation. Although the mechanisms by which vitamin $C$ modulates stem cell biology are unclear, the revision presented here suggests a unique role for vitamin $C$ during stem cell transplantation in a number of brain diseases.

\subsection{Vitamin $C$ in the central nervous system}

Most mammals are able to synthesize vitamin C from glucose. Humans and primates however are deficient in the enzyme that catalyzes vitamin C biosynthesis (L-.gulonolactone oxidase); therefore, they must obtain it from the diet (Nishikimi and Yagi, 1991). Lack of vitamin C during development and/ or adulthood can produce severe physiological disorders that could lead to death, implying that as micronutrient, vitamin $C$ is essential for the normal functioning of the organism (Harrison and May, 2009; Rice, 2000; Tveden-Nyborg et al., 2009). Its best known role is that of an antioxidant agent, taking away highly reactive free radicals that are constantly generated by the cellular machinery (Arrigoni and De Tullio, 2002; Harrison and May, 2009; Nualart et al., 2003; Wayner et al., 1986). This role is highly relevant for both the maintenance of cerebral functions and protection of brain structures (Rice, 2000). Given that the brain is among the organs with the highest rate of metabolism, it is subjected to elevated levels of oxidative stress, and thus high levels of vitamin $C$ are required.

In addition to its protective role, vitamin $\mathrm{C}$ acts as a cofactor in several enzymatic reactions. It participates in the synthesis of catecholamines, carnitine (Rebouche, 1991), cholesterol, amino acids, and several other hormonal peptides (Glembotski, 1987). It also facilitates the hydroxylation of proline and lysine residues in collagen, which are required for its correct folding (Murad et al., 1981; Peterkofsky, 1972 , 1991) as well as the hydroxylation of hypoxiainducible factor-1 alpha (HIF1a), which is degraded by the proteosome under normal oxygen conditions (Harrison and May, 2009). Recent investigation indicates that vitamin $\mathrm{C}$ modulates dopaminergic, glutamatergic and cholinergic neurotransmission (Rebec and Pierce, 1994; Sandstrom and Rebec, 2007).

Vitamin C can also promote myelin formation (Eldridge et al., 1987). Using adult salamander dorsal root ganglia, Olsen and Bunge (1986) observed myelination in vitro and described vitamin $C$ as a critical factor for Schwann cell myelination. Similarly, Eldridge et al. (1987) described that chick embryo extracts and L-AA led to the formation of large quantities of myelin and to the assembly of basal laminae. They strongly suggest that AA promotes Schwann cell myelin formation. Furthermore, in vitro and animal studies showed that AA improves the clinical and pathological phenotype of a mouse model of Chercot-Marie-tooth disease 1A (CMT1A) (Kaya et al., 2007; Passage et al., 2004), which led to various clinical trials examining AA administration in CMT1A. However, none of these trials showed a significant benefit of AA in the treatment of CMT1A patients (Burns et al., 2009; Micallef et al., 2009; Verhamme et al., 2009). The lack of effectiveness in the treatments was difficult to interpret because there were no studies assessing SVCT2 expression in Schwann cells and peripheral nerves, data that was recently obtained by (Gess et al., 2010). Additionally, they used the heterozygous SVCT2+ / - 
mice to elucidate the functions of SVCT2 and AA in the murine peripheral nervous system. SVCT2 deficiency causes hypomyelination and extracellular matrix defects in peripheral nervous system (Gess et al., 2011). Also, they demonstrated that expression of various collagen types was reduced in the sciatic nerves of $\mathrm{SVCT}^{+/-}$mice, and hydroxyproline levels were surprisingly normal. These results indicate that collagen formation was regulated on the transcriptional and not the posttranslational level (Gess et al., 2011).

\subsection{Vitamin $C$ transporters in the brain}

Two types of proteins are required for the uptake and maintenance of vitamin C levels in the brain: the sodiumascorbate co-transporters (SVCTs) and the hexose transporters
(GLUT1, GLUT3, GLUT4), the latter incorporating only the oxidized form of vitamin C (Nualart et al., 2003; Rumsey et al., 2000; Rumsey et al., 1997; Vera et al., 1993). Therefore, SVCTs are the major homeostatic regulators of vitamin $C$ levels in the central nervous system (CNS; Rice, 2000), actively uptaking its reduced form, L-ascorbate (Caprile et al., 2009; Castro et al., 2001; Garcia et al., 2005). L-ascorbate is transported against its concentration gradient (Daruwala et al., 1999; Tsukaguchi et al., 1999), and thus the energy required for the transport is supplied by sodium exchange through the $\mathrm{Na}^{+} / \mathrm{K}^{+}$-ATPase pump (Castro et al., 2001). The relationship between sodium and ascorbate transport was found to be 2:1, and the order of union to the substrate was sodium-ascorbate-sodium (Godoy et al., 2007). At the molecular level, two SVCTs (SVCT1 and SVCT2) encoded by different genes have been described
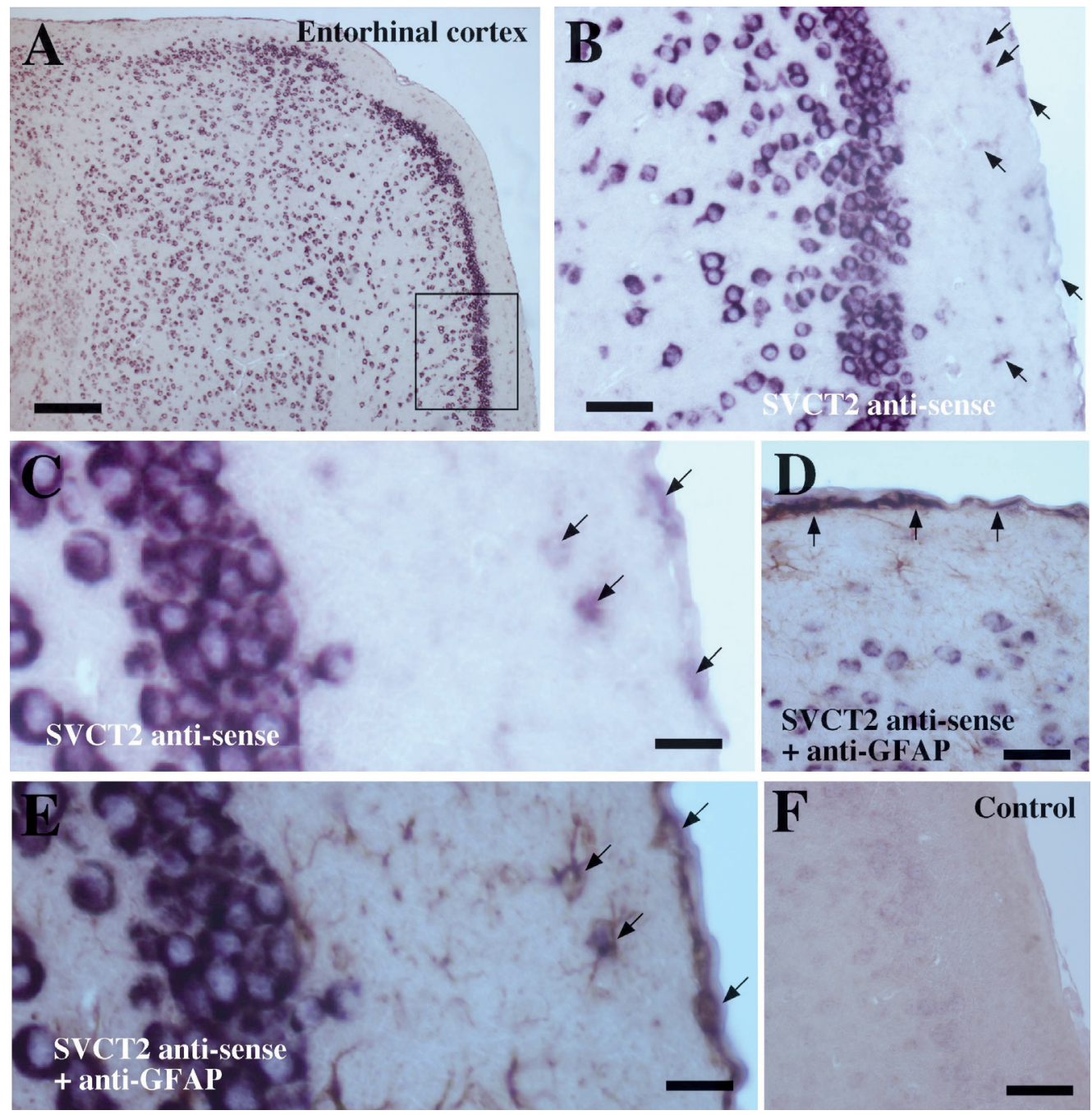

Figure 4. SVCT2 mRNA detection by in situ hybridization in adult brain: SVCT2 expression at the mRNA level by in situ hybridization using digoxigenin-labeled cRNA probes specific for SVCT2. An intense hybridization signal was observed in different neurons of the mouse brain, the most intense signal was detected in hippocampus, thalamic nuclei, hypothalamus and the entorhinal cortex (A, B, C). No labeling was detected in endothelial cells of the blood-brain barrier and astrocytes. To confirm the presence of negatively-labeled astrocytes in the tissue sections, we carried out in situ hybridization for SVCT2 in combination with immunohistochemical analysis using antibodies against GFAP and a peroxidase-labeled secondary antibody (D-E, arrows). Most astrocytes were negative for SVCT2 in the different areas of the brain (B-C); however, the astrocytes detected in the external area of the entorhinal cortex and marginal zone of the brain showed SVCT2 expression (C, D and E, arrows). Experiments using an antisense for SVCT2 and anti-GFAP in the same section confirmed SVCT2 expression in GFAP-positive cells (C and E, arrows). F, Control experiments using a sense riboprobe. Scale bars: $20 \mu \mathrm{m}$. 
(Faaland et al., 1998; Tsukaguchi et al., 1999; Wang et al., 1999). Each transporter has a distinct distribution. For example, in situ hybridization and immunohistochemical experiments have shown that SVCT2 is expressed mostly in CNS within choroid plexus cells (Garcia et al., 2005; Tsukaguchi et al., 1999), embryonic neurons (Castro et al., 2001), tanycytes (Garcia et al., 2005) and adult cortical and hippocampal neurons (Astuya et al., 2005) (Figure 4A-B). Although most astrocytes do not express SVCT2, our results indicate that astrocytes of the external area of the entorhinal cortex express SVCT2 (Figure $4 \mathrm{C}, \mathrm{E})$. Additionally, glia limitans, the thin barrier of astrocytes associated with the parenchymal basal lamina surrounding the brain, also showed double labeling for SVCT2 and GFAP (Figure 4C-E, arrows). In contrast, SVCT1 is typically found in peripheral organs, such as kidney, intestine, or liver (Castro et al., 2008; Tsukaguchi et al., 1999). Cloned for the first time by Tsukaguchi et al. (1999), both transporters share an amino acid identity sequence of $60-65 \%$, and according to predictions of hydrophobicity, each has 12 transmembrane domains with the $\mathrm{N}$ - and C-terminal domains facing the cytosolic side (Savini et al., 2008). SVCT1 and SVCT2 have "non-functional" variants generated by alternative splicing. In the case of SVCT2, Lutsenko et al. (2004) described a short isoform that lacks the transmembrane segment of domains 4, 5 and 6 (Lutsenko et al., 2004). This isoform acts as a dominant negative when inhibiting the transport of ascorbate mediated by the complete isoform of SVCT2. The expression of both SVCTs is regulated at different levels: transcriptionally by the presence of two promoting sequences with distinct efficiencies in SVCT2, and post-transductionally by the presence of phosphorylation and glycosylation sites in SVCT1 and SVCT2. Recently, these cellular modifications were described as determinant of the functionality and subcellular localization of these transporters (Subramanian et al., 2008).

Different research groups have shown the physiological importance of both transporters. Sotiriou et al. (2002) generated knockout mice for the gene encoding SVCT2, and observed that animals developed respiratory problems and cerebral hemorrhages dying within minutes immediately after birth. Biochemical analysis showed that vitamin C levels in brain and other areas were undetectable, indicating that SVCT2 is critical for the maintenance of vitamin C levels. The cerebral hemorrhages observed in these animals suggest poor formation of collagen, which requires vitamin $\mathrm{C}$ as cofactor for its synthesis (Sotiriou et al., 2002). Histological analysis showed no morphological alterations at the cerebral level, suggesting that SVCT2 is not required at least in part for brain development. The above leaves open the possibility that other isoforms of the transporter not yet identified contribute to the incorporation of vitamin $\mathrm{C}$ to trigger the differentiation of cerebral cells.

\subsection{Vitamin $C$ and stem cell differentiation}

Recently, Pei and colleagues (2010) found that vitamin C favored the generation of induced pluripotent stem cells (iPS) (Esteban et al., 2010). Cells grown in vitro in the presence of vitamin C expressed two histone demethylases, Jhdm1a and Jhdm1b (Wang et al., 2011), which are required for iPS cells production. Vitamin C also helped to maintain iPS cells in vitro, which favored their proliferation (Esteban et al., 2010). The increase in the number of iPS was found to be mediated at least in part by a reduction in the levels of p53, the tumor suppressor protein that elicits cell death (Esteban et al., 2010). Together, these results suggest that vitamin $C$ is able to positively regulate stem cell generation and proliferation.

Neural tissue has been shown to attain ascorbic acid (AA) concentrations that rank among the highest of mammalian tissues (Horning et al., 1975; Kratzing et al., 1982; Milby et al., 1982). In fact, vitamin C levels are particularly high in fetal rat brain, doubling from the 15th to the 20th day of gestation and then dropping significantly by the time of birth (Kratzing et al., 1985). A similar pattern was observed in chicken embryos in which the AA concentration increased to $5.6 \mathrm{nmol} / \mathrm{mg}$ by D10 in ovo, and gradually declined to $32 \%$ before birth (Wilson, 1990). Surprisingly, normal brain differentiation has been observed in SVCT-null mice, suggesting that embryonic cells may use different mechanisms or transporters to take up and maintain high levels of vitamin C (Sotiriou et al., 2002). Recently, Yan and collaborators (Yang et al., 2001) reported high expression of SVCT2 in embryonic mesencephalic neurons, and suggested an important role for vitamin $C$ in dopaminergic differentiation. They observed that the stem cells grown with AA gave rise to a 10 -fold increase in the number of dopaminergic neurons compared to the untreated cultures (Yang et al., 2001).

To characterize the localization of the vitamin $C$ transporter, SVCT2, in early brain development, the expression of SVCT2 was examined through RT-PCR in fetal mouse brain. High levels of SVCT2 expression were observed in the cerebellum, hippocampus, and hypothalamus (Castro et al., 2001). Kinetic analysis of AA uptake in primary neuronal cultures showed two affinity constants, 8 and $103 \mathrm{uM}$. The first kinetic constant is in accordance with previous reports for SVCT2 (Tsukaguchi et al., 1999). The second kinetic constant suggests an alternative path for the transport of vitamin C in mouse embryonic neurons. Because the sole presence of a given mRNA does not always correlate with protein expression and functional activity, it is, therefore, necessary to study both mRNA expression and protein distribution to obtain a more definitive answer regarding the expression and localization of SVCT2 in fetal rat brain. By a variety of methods, Caprile and collaborators demonstrated that SVCT2 is highly expressed in the ventricular and subventricular areas of fetal rat brain. Further functional analysis carried out in immature neurons isolated from either embryonic brain cortex or cerebellum showed that SVCT2 is localized in the cellular membrane and is involved in vitamin C uptake in these cells (Caprile et al., 2009). Similar results have been obtained in Neuro2a and HN33.11 cell lines, demonstrating that SVCT2 is critical for vitamin C transport (Caprile et al., 2009). In line with our hypothesis, SVCT2 has also been implicated in neuronal maturation possibly by regulating the differentiation of embryonic cortical precursors into neurons and astrocytes. AA promoted in vitro differentiation of CNS precursor cells into neurons and astrocytes in a cell density-dependent manner (Lee et al., 2003). Also, AA seems to affect the functional maturation of post-mitotic neurons. For example, the addition of AA to these neurons enhanced the frequency and amplitude of synaptic potentials, an effect that was dose-dependent and highly specific (Lee et al., 2003). An AA-dependent increase in the expression of genes, which could potentially compound the effects of AA on cell differentiation, was also observed (Qiu et al., 2007), suggesting that AA may stimulate the brain in the 
generation of CNS neurons and glia. It has also been observed that in cultured hippocampal neurons, SVCT2 was required for normal maturation of glutamatergic function (Qiu et al., 2007). Hippocampal neurons from days 16-18 in utero Slc23a2-/- and wild-type embryos were isolated from mice and functionally compared. It was consistently seen that the lack of SVCT2 resulted in smaller amplitude of synaptic potentials, and these mice also exhibited less complexity in terms of number of primary dendrites as well as total dendrite length (Qiu et al., 2007). Hippocampal neurons from Slc23a2-/- embryos lack AA while the intracellular concentration in wild-type neurons was within the range of 0.1-0.2mM (Qiu et al., 2007).

How does vitamin $\mathrm{C}$ promote stem cell differentiation? How do neural stem cells, or any other pluripotent cell, uptake vitamin C? What set of transporters are present in these cells? The answers to these questions are necessary to understand the role of vitamin $C$ in neural stem cell differentiation.

\section{ROLE OF VITAMIN C IN BRAIN STEM CELL TRANSPLANTA- TION}

\subsection{Stem cell transplantation in the CNS}

Stem cell transplantation has emerged as a unique therapeutic strategy for most neurological disorders (i.e., Parkinson's Disease (PD), Alzheimer's Disease (AD), Amyotrophic Lateral Sclerosis (ALS), Spinal Muscular Atrophy (SMA), stroke, etc.). The goal of this strategy is the partial or complete replacement of damaged or dead neural cells by newer and healthier ones, which in theory should lead to functional restoration of the afflicted tissue. Depending on the type of cells used (e.g., induced pluripotent, embryonic or adult stem cells), their physiological and metabolic state and the disease to be targeted, stem cell transplantation therapy has obtained promising results (see below). The low number of cells transplanted, their limited survival, decreased differentiation efficiency, poor cellular integration, in addition to tissue immune rejection, are all factors that lead to inconsistencies in the results. In spite of these problems, the scientific optimism for cellular transplantation keeps growing, with the National Institute of Health (USA) devoting additional resources to it.

We describe below some of the neurodegenerative diseases being considered for "treatment" with stem cell transplantation, their results and problems, and the future directions of the approach. In this context, we speculate that the treatment with vitamin $C$ acts in favor of cellular replacement in all disorders listed.

\subsection{Stem cell transplantation in neurodegenerative disorders}

\subsubsection{Parkinson's disease}

Parkinson's disease (PD) is a progressive neurological disorder that affects $\sim 1 \%$ of the population over 55 years of age. It is caused by the progressive loss of dopaminergic neurons from the Substantia Nigra and Corpus Striatum, which provokes severe motor dysfunctions, including uncontrollable shaking, rigidity, walking and coordination problems, and at later stages, cognitive and behavioral deficits. Although the cause(s) of dopaminergic neuronal loss is (are) unknown, a distinctive feature of PD is the accumulation of filamentous inclusions known as Lewy bodies, which consist of protein aggregates formed mainly by $\alpha$-synuclein, ubiquitin and neurofilaments (Trojanowski and Lee, 1998). The current view is however that Lewy bodies are a consequence and not a cause of the disease. A more recent hypothesis suggests that metabolic alterations in dopaminergic neurons are the primary cause of PD. To support this view, a number of labs have shown that the enzymes involved in the metabolism of dopamine produce elevated quantities of $\mathrm{H}_{2} \mathrm{O}_{2}$ (Przedborski et al., 2000). In the presence of oxygen, these peroxide species form reactive oxygen species (ROS), which at augmented levels alter the health of the neurons. Additionally, dopaminergic cells are highly dependent on adenosine triphosphate, and inhibitors of mitochondrial function (i.e., MPP) accumulate specifically in dopaminergic neurons, affecting their ATP production and promoting the generation of ROS (Winklhofer and Haass, 2010). More recently, several genes have been linked to mitochondrial dysfunction and have been consequently implicated in PD (Blandini and Armentero, 2012; Winklhofer and Haass, 2010). Although the mechanism through which these genes alter free radical generation and mitochondrial function specifically in dopaminergic neurons is not yet clear, the excessive production of free radicals coupled with perturbed mitochondrial function strongly correlates with dopaminergic neuronal death (Betarbet et al., 2002a; Betarbet et al., 2002b; Winklhofer and Haass, 2010).

Levodopa is currently the only pharmacological option with a recognized effect on stopping the progression of PD; it allows the recovery of dopamine levels in the afflicted areas, which in turn alleviates the motor defects observed in PD patients (Dawson et al., 2010). Unfortunately, the effectiveness of the treatment decreases with time (Dawson et al., 2010). Due to this, and the lack of pharmacological alternatives, stem cell transplantation has emerged as a compelling strategy to restore dopaminergic neurons in PD patients. In theory, stem cells have the potential to generate an unlimited number of dopaminergic neurons. In practice, it has been tremendously difficult to produce them (Cao et al., 2001; Li et al., 2007). By over-expressing genes that encode transcription factors present primarily in dopaminergic neurons, embryonic stem cells have been derived into dopaminergic neurons in vitro (Jacobs et al., 2009; Perrier et al., 2004). These pioneer results immediately raised the possibility of transplanting dopaminergic neurons in PD animal models (Kriks et al., 2011; Tabar et al., 2008) and patients. Kriks and colleagues (2011) were the first to introduce stem cell-derived dopaminergic neurons into PD mice. Transplanted neurons survived, integrated into the mature neuronal parenchyma and established neural connections with the existent neurons (Kriks et al., 2011). More importantly, these cellular transplants were able to significantly improve motor function in PD mice (Kriks et al., 2011). Several labs are now trying to inject stem cell-derived dopaminergic neurons into human PD patients.

Although the results in animal models are quite encouraging, stem cell transplantations have not been exempt of problems. A large number of the transplanted cells often die after the procedure, reducing the possibilities of replacing the damaged cells. In other cases, the newly differentiated neurons become pluripotent cells again, and no longer express the identifying dopaminergic factors. A major problem is that the exogenous transplants may generate aggressive tumors, making the treatment strategy quite dangerous. It is therefore fundamental to solve these and other problems before stem cell 
therapy could be used safely and efficiently in human patients. It is also of major priority to understand the factors that might regulate stem cell transplantation in $\mathrm{PD}$ patients. In this context, experimental evidence suggests that vitamin $C$ might positively modulate stem cell transplantation. First, as an antioxidant, vitamin $C$ can drastically reduce the accumulation of free radicals produced by both the endogenous tissue, and the stem cell-derived neurons exogenously incorporated into the tissue. The scavenging effect of vitamin $\mathrm{C}$ has an important consequence; it dramatically reduces cell death. Such improvement in survival should have a direct impact on the number of stem cell-derived neurons available for insertion into the afflicted tissue. Thus, vitamin $C$ indirectly modulates neuronal integration. A second role of vitamin $C$ is to directly favor stem cell production and differentiation into dopaminergic neurons. The idea is supported by preliminary results in which mouse or human somatic cells incubated with vitamin $C$ significantly increased the induction of stem cells (Esteban et al., 2010; Yan et al., 2001), a mechanism mediated at least in part by regulating the activity of histone demethylases, enzymes required for the expression of Nanog (a master transcription factor for stem cell production). In other experiments, vitamin $\mathrm{C}$ has been directly implicated in cellular differentiation. Stem cells incubated with vitamin $C$ increased the number of cells that acquired a cardiac phenotype (i.e., contractile properties and GATA4, a and b-myosin heavy chain expression). Similarly, it is possible that under appropriate conditions, vitamin $C$ can promote specific neuronal differentiation (Figure 5). In general, we believe vitamin $\mathrm{C}$ is a promising co-adjuvant to achieve successful stem cell transplantation in PD.

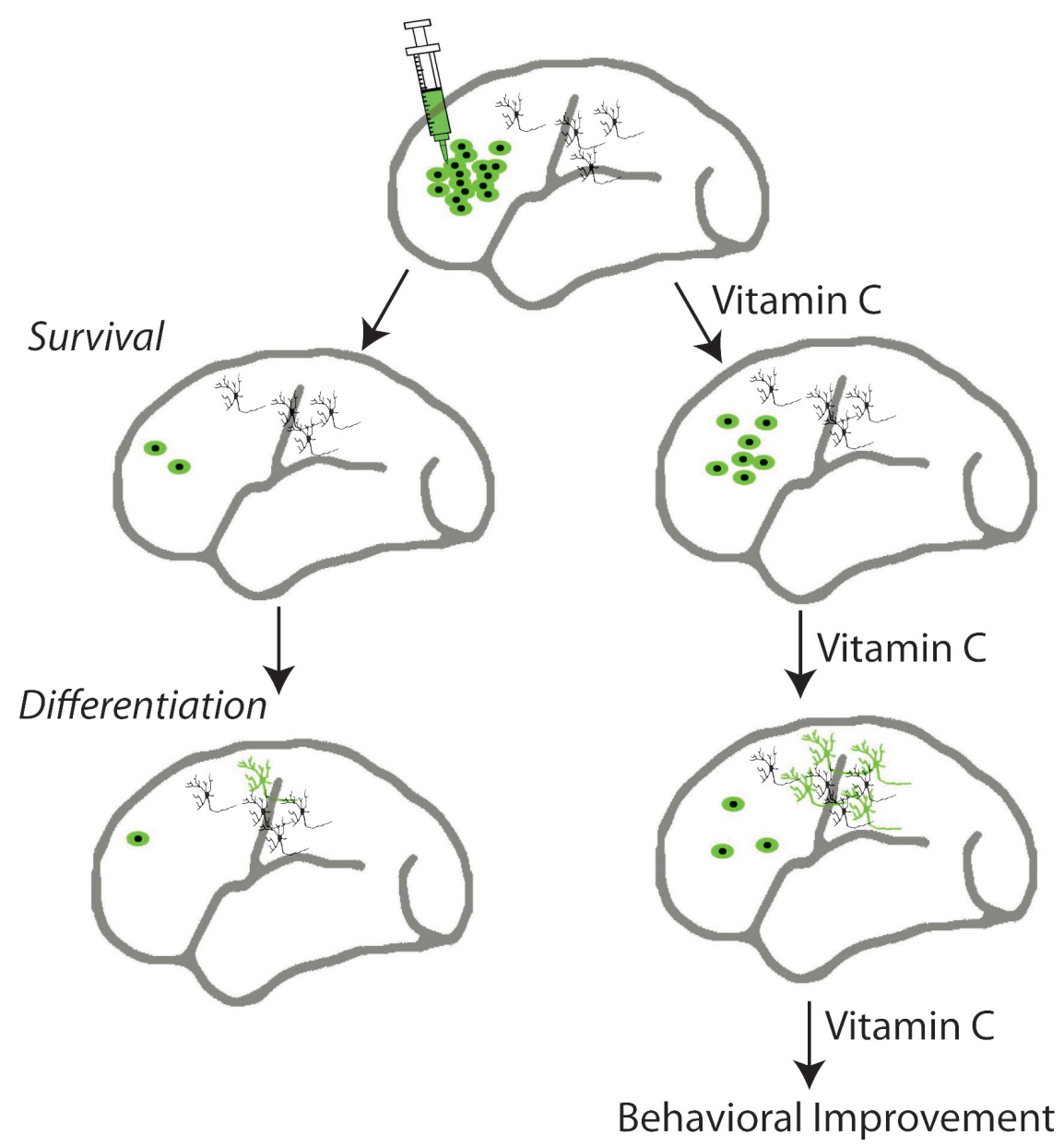

Figure 5. Vitamin C promotes survival, proliferation and differentiation of pluripotent stem cells upon transplantation in neurodegenerative disorders: In all neurodegenerative diseases, patients' lives are dramatically altered by the massive loss of neurons associated with the disease (black cells, panel). Transplantation of stem cells aims to replace the damaged tissue (injection of cells, needle, top) and correct most of the functional defects. To date, replacement therapies have generally been unsuccessful because of both the low level of stem cell survival (left, middle panel), and limited and unspecific differentiation (left, bottom panel). Vitamin C may positively regulate the outcome of stem cell therapy by regulating such cellular events (right). In presence of vitamin C, transplanted stem cells (green) become healthier (less free radical agents) favoring cellular survival and thus proliferation. This step increases the number of cells available for tissue replacement (right, middle panel). In a second step, vitamin C modulates stem cell differentiation (right, middle panel). Acting via currently unknown pathways, vitamin $\mathrm{C}$ induces the formation of specific cells types (in this case neurons, green), which upon proper integration, recreates the previously defective neuronal network (green and black neurons). Thus, vitamin $\mathrm{C}$ might ultimately lead to an improvement of behavioral alterations. 


\subsubsection{Alzheimer's disease}

Alzheimer's disease (AD) is a devastating neurodegenerative disorder. It is characterized by the progressive loss of memory and cognitive function. Although the exact mechanistic cause(s) of $\mathrm{AD}$ is (are) unknown, experimental evidence has guided our attention to the accumulation of beta-amyloid peptide (A $\beta$-plaques) and hyperphosphorylated tau proteins (neurofibrillary tangles, NFTs) (Lambert et al., 1998; Lee et al., 2005). Animal models of AD in which A $\beta$ plaques or NFT are expressed, have become the standard tools to study the cellular and molecular alterations present in neurons undergoing $\mathrm{AD}$ (Morgan et al., 2000; Mucke et al., 2000; Woodruff-Pak, 2008). Although our understanding has grown significantly in recent years, there is limited treatment for the disease (Morgan et al., 2000). The main complication for any therapeutical approach is that almost all neurons (i.e., inhibitory and excitatory neurons as well as local or projection neurons) are equally affected in AD (Woodruff-Pak, 2008). Thus, AD has no unique cellular target. A further complication is that $\mathrm{AD}$ affects not just one brain region but several, including cortex, hippocampus and brain stem neurons.

Stem cell transplantation is considered the restorative solution for Alzheimer's patients. However, transplantation in $\mathrm{AD}$ patients is complicated by the factors previously indicated (i.e., variety of cells undergoing degeneration and brain regions afflicted). Despite this fundamental problem, researchers have injected stem cells or stem cell-derived neurons into various brain regions in $\mathrm{AD}$ mouse models with the hope of restoring brain function. While in some cases the transplanted animals showed no improvement, in others stem cell transplantation produced a substantial improvement in cognitive function (Blurton-Jones et al., 2009; Marutle et al., 2007). The mechanisms by which these stem cell transplants achieved behavioral improvements are however controversial; optimistic researchers have suggested that the improvement is due to the replacement of damaged neurons (Marutle et al., 2007). However, more conservative investigators indicate that the injected stem cells did not replace damaged neurons but instead released trophic factors (e.g., BDNF, brain derived neurotrophic factor; NT-3, neurotrophin 3) that support cell survival and neuronal plasticity (Blurton-Jones et al., 2009). Further experiments are necessary to clarify such controversy. In any case, the results indicate that stem cell transplantation is a potentially valuable alternative for $\mathrm{AD}$ patients. As we indicated previously, stem cell transplantation can be enhanced by treating the patients with vitamin $C$ because it quenches free radicals and promotes survival of the transplanted stem cell-derived neurons (Figure 5). Such improvement in neuronal survival should favor the insertion of the newly transplanted neurons into the afflicted tissue (Figure 5). In addition, vitamin $\mathrm{C}$ should also enhance the proliferation and differentiation of stem cells (described above). Future experiments are necessary to support our view.

\subsubsection{Amyotrophic lateral sclerosis}

Amyotrophic Lateral Sclerosis (ALS) is a fatal and progressive disease in which spinal cord motor neurons die. As motor neurons and their neuromuscular connections degenerate, muscle strength decays, leading to paralysis and respiratory failure (Donkervoort and Siddique, 1993). A number of comprehensive studies have determined that approximately $10 \%$ of the ALS cases are caused by inherited genetic defects, while the rest of the cases have no obvious familial background (Blauw et al., 2012). Of the genes implicated in ALS, some (SOD1) encode proteins present in the mitochondria (e.g., copper-zinc superoxide dismutase type 1, SOD1) while others encode proteins that bind to DNA/RNA sequences (e.g., fused in sarcoma/translocation in liposarcoma, FUS/TLS; and $43 \mathrm{kDa}-\mathrm{TAR}-\mathrm{DNA}$ binding protein; TDP43). Mutations in any of these genes cause ALS. For example, SOD1 mutations (G93A) alone in motor neurons and glial cells or motor neurons can cause their loss (Renton et al., 2011; Traub et al., 2011). Aberrant mitochondrial function, endoplasmic reticulum stress, axonal transport defects, and the excessive production of free radicals species have been suggested as the main causes of motor neuron degeneration (Papadeas et al., 2011; Philips and Robberecht, 2011; Van Den Bosch et al., 2006; Yamanaka et al., 2008). How the mutations in TDP43 and FUS/TLS produce motor neuron death remains less clear. Alterations in the regulation of gene expression, RNA splicing, RNA transport and translation, as well as microRNA processing have all been implicated as causes of the disease (Buratti and Baralle, 2008). More recently, a new genomic factor was found to be responsible for ALS; the presence of hexanucleotide repeats in a gene known as C9ORF72, which has no known function (DeJesus-Hernandez et al., 2011; Renton et al., 2011), directly correlates with many ALS cases. Together, these findings have the potential to lead us to significant advances into understanding how the disease develops. Clinically, however there are no options; no drug has been able to stop or even delay ALS progression. For this reason, stem cell transplantation has emerged as a distinctive strategy to replace ALS afflicted motor neurons and glial cells (Kim et al., 2010; Lepore et al., 2008) . Indeed, it has been possible to differentiate stem cells into either motor neurons or glial cells in vitro (Dimos et al., 2008; Karumbayaram et al., 2009; Song et al., 2011). In a transgenic mouse model of ALS, stem cell transplantation delayed the disease progression, reduced motor neuron loss and improved motor function (Lepore et al., 2008). More recently, clinical trials of human ALS patients treated with either autologous or xenogenous neuronal stem cells are underway.

As with $\mathrm{PD}$ and $\mathrm{AD}$, we believe vitamin $\mathrm{C}$ treatment could positively favor stem cell transplantation in ALS patients by first reducing the generation of free radicals, which are particularly toxic for motor neurons that contain low amount of molecular scavengers. Therefore, vitamin $C$ should promote the survival of both differentiated and transplanted stem cellderived motor neurons (Figure 5). Vitamin C should also help to promote stem cell proliferation, and differentiation by the mechanisms previously described (see above). Validation of the predicted adjuvant role of vitamin C in ALS remains to be demonstrated.

\section{ACKNOWLEDGMENTS}

This work was supported by a grant from the Fondo Nacional de Ciencia y Tecnología (FONDECYT 1100396) to FN and Alliance Therapy for Amyotrophic Lateral Sclerosis to JCT. The authors thank Dr. Masahiko Watanabe, Department of Anatomy, Hokkaido University School of Medicine, Sapporo, Japan for the donation of the antibody, anti-3-PGDH. We also 
thank Dr. Marjet Heitzer for critical reading and editing of the manuscript and Msc. Joanna Tereszczuk for technical support in image processing, Center for Advanced Microscopy, CMA Bio Bio (www.cmabiobio.cl).

\section{REFERENCES}

AIGNER A, RAY PE, CZUBAYKO F, WELLSTEIN A. (2002) Immunolocalization of an FGF-binding protein reveals a widespread expression pattern during different stages of mouse embryo development. Histochem Cell Biol 117:1-11.

ÁLVAREZ-BUYLLA A, GARCÍA-VERDUGO JM, MATEO AS, MERCHANTLARIOS H. (1998) Primary neural precursors and intermitotic nuclear migration in the ventricular zone of adult canaries. J Neurosci 18:10201037.

ANTHONY TE, KLEIN C, FISHELL G, HEINTZ N. (2004) Radial glia serve as neuronal progenitors in all regions of the central nervous system. Neuron 41:881-890.

ARRIGONI O, DE TULLIO MC. (2002) Ascorbic acid: much more than just an antioxidant. Biochim Biophys Acta 1569:1-9.

ASTUYA A, CAPRILE T, CASTRO M, SALAZAR K, GARCÍA MDE L, REINICKE K, RODRÍGUEZ F, VERA JC, MILLÁN C, ULLOA V, LOW M, MARTÍNEZ F, NUALART F. (2005) Vitamin C uptake and recycling among normal and tumor cells from the central nervous system. J Neurosci Res 79:146-156.

BARNABE-HEIDER F, WASYLNKA JA, FERNANDES KJ, PORSCHE C, SENDTNER M, KAPLAN DR, MILLER FD. (2005) Evidence that embryonic neurons regulate the onset of cortical gliogenesis via cardiotrophin-1. Neuron 48:253-265.

BARTKOWSKA K, TURLEJSKI K, GRABIEC M, GHAZARYAN A, YAVRUOYAN E, DJAVADIAN RL. (2010) Adult neurogenesis in the hedgehog (Erinaceus concolor) and mole (Talpa europaea). Brain Behav Evol 76:128-143.

BEHAR TN, SCHAFFNER AE, COLTON CA, SOMOGYI R, OLAH Z, LEHEL C, BARKER JL. (1994) GABA-induced chemokinesis and NGF-induced chemotaxis of embryonic spinal cord neurons. J Neurosci 14:29-38.

BETARBET R, SHERER TB, DI MONTE DA, GREENAMYRE JT. (2002a) Mechanistic approaches to Parkinson's disease pathogenesis. Brain Pathol 12:499-510.

BETARBET R, SHERER TB, GREENAMYRE JT. (2002b) Animal models of Parkinson's disease. Bioessays 24:308-318.

BHATTACHARYA S, DAS AV, MALLYA KB, AHMAD I. (2008) Ciliary neurotrophic factor-mediated signaling regulates neuronal versus glial differentiation of retinal stem cells/progenitors by concentrationdependent recruitment of mitogen-activated protein kinase and Janus kinase-signal transducer and activator of transcription pathways in conjunction with Notch signaling. Stem Cells 26:2611-2624.

BLANDINI F, ARMENTERO MT. (2012) Animal models of Parkinson's disease. FEBS J 279:1156-1166.

BLAUW HM, BARNES CP, VAN VUGHT PW, VAN RHEENEN W, VERHEUL M, CUPPEN E, VELDINK JH, VAN DEN BERG LH. (2012) SMN1 gene duplications are associated with sporadic ALS. Neurology 78:776-780.

BLURTON-JONES M, KITAZAWA M, MARTÍNEZ-CORIA H, CASTELLO NA, MULLER FJ, LORING JF, YAMASAKI TR, POON WW, GREEN KN, LAFERLA FM. (2009) Neural stem cells improve cognition via BDNF in a transgenic model of Alzheimer disease. Proc Natl Acad Sci U S A 106:13594-13599.

BONNI A, SUN Y, NADAL-VICENS M, BHATT A, FRANK DA, ROZOVSKY I, STAHL N, YANCOPOULOS GD, GREENBERG ME. (1997) Regulation of gliogenesis in the central nervous system by the JAK-STAT signaling pathway. Science 278:477-483.

BURATTI E, BARALLE FE. (2008) Multiple roles of TDP-43 in gene expression, splicing regulation, and human disease. Front Biosci 13:867-878.

BURNS J, OUVRIER RA, YIU EM, JOSEPH PD, KORNBERG AJ, FAHEY MC, RYAN MM. (2009) Ascorbic acid for Charcot-Marie-Tooth disease type $1 \mathrm{~A}$ in children: a randomised, double-blind, placebo-controlled, safety and efficacy trial. Lancet Neurol 8:537-544

CAO QL, ZHANG YP, HOWARD RM, WALTERS WM, TSOULFAS P, WHITTEMORE SR. (2001) Pluripotent stem cells engrafted into the normal or lesioned adult rat spinal cord are restricted to a glial lineage. Exp Neurol 167:48-58.

CAPRILE T, SALAZAR K, ASTUYA A, CISTERNAS P, SILVA-ÁLVAREZ C, MONTECINOS H, MILLÁN C, DE LOS ÁNGELES GARCÍA M,
NUALART F. (2009) The Na+-dependent L-ascorbic acid transporter SVCT2 expressed in brainstem cells, neurons, and neuroblastoma cells is inhibited by flavonoids. J Neurochem 108:563-577.

CASTRO M, CAPRILE T, ASTUYA A, MILLAN C, REINICKE K, VERA JC, VASQUEZ O, AGUAYO LG, NUALART F. (2001) High-affinity sodiumvitamin C co-transporters (SVCT) expression in embryonic mouse neurons. J Neurochem 78:815-823.

CASTRO T, LOW M, SALAZAR $\mathrm{K}$, MONTECINOS $\mathrm{H}$, CIFUENTES M, YÁÑEZ AJ, SLEBE JC, FIGUEROA CD, REINICKE K, DE LOS ÁNGELES GARCÍA M, HENRÍQUEZ JP, NUALART F. (2008) Differential distribution of the Sodium-vitamin C cotransporter-1 along the proximal tubule of the mouse and human kidney. Kidney Int 74:1278-1286.

CHOJNACKI AK, MAK GK, WEISS S. (2009) Identity crisis for adult periventricular neural stem cells: subventricular zone astrocytes, ependymal cells or both? Nat Rev Neurosci 10:153-163.

CICCOLINI F. (2001) Identification of two distinct types of multipotent neural precursors that appear sequentially during CNS development. Mol Cell Neurosci 17:895-907.

CIFUENTES M, PÉREZ-MARTIN M, GRONDONA JM, LÓPEZ-ÁVALOS MD, INAGAKI N, GRANADOS-DURÁN P, RIVERA P, FERNÁNDEZLLEBREZ P. (2011) A comparative analysis of intraperitoneal versus intracerebroventricular administration of bromodeoxyuridine for the study of cell proliferation in the adult rat brain. J Neurosci Methods 201:307-314.

COLOMBO JA, NAPP M, DEPAOLI JR, PUISSANT V. (1993) Trophic influences of human and rat amniotic fluid on neural tube-derived rat fetal cells. Int J Dev Neurosci 11:347-355.

CORTÉS-CAMPOS C, ELIZONDO R, LLANOS P, URANGA RM, NUALART F, GARCÍA MA. (2011) MCT expression and lactate influx/efflux in tanycytes involved in glia-neuron metabolic interaction. PLoS One 6:e16411.

CULICAN SM, BAUMRIND NL, YAMAMOTO M, PEARLMAN AL. (1990) Cortical radial glia: identification in tissue culture and evidence for their transformation to astrocytes. J Neurosci 10:684-692.

DARUWALA R, SONG J, KOH WS, RUMSEY SC, LEVINE M. (1999) Cloning and functional characterization of the human sodium-dependent vitamin C transporters hSVCT1 and hSVCT2. FEBS Lett 460:480-484.

DAWSON TM, KO HS, DAWSON VL. (2010) Genetic animal models of Parkinson's disease. Neuron 66:646-661.

DEJESUS-HERNÁNDEZ M, MACKENZIE IR, BOEVE BF, BOXER AL, BAKER M, RUTHERFORD NJ, NICHOLSON AM, FINCH NA, FLYNN H, ADAMSON J, KOURI N, WOJTAS A, SENGDY P, HSIUNG GY, KARYDAS A, SEELEY WW, JOSEPHS KA, COPPOLA G, GESCHWIND DH, WSZOLEK ZK, FELDMAN H, KNOPMAN DS, PETERSEN RC, MILLER BL, DICKSON DW, BOYLAN KB, GRAFF-RADFORD NR, RADEMAKERS R. (2011) Expanded GGGGCC hexanucleotide repeat in noncoding region of C9ORF72 causes chromosome 9p-linked FTD and ALS. Neuron 72:245-256.

DEL BENE F, WEHMAN AM, LINK BA, BAIER H. (2008) Regulation of neurogenesis by interkinetic nuclear migration through an apical-basal notch gradient. Cell 134:1055-1065.

DIMOS JT, RODOLFA KT, NIAKAN KK, WEISENTHAL LM, MITSUMOTO H, CHUNG W, CROFT GF, SAPHIER G, LEIBEL R, GOLAND R, WICHTERLE H, HENDERSON CE, EGGAN K. (2008) Induced pluripotent stem cells generated from patients with ALS can be differentiated into motor neurons. Science 321:1218-1221.

DOETSCH F, GARCÍA-VERDUGO JM, ÁLVAREZ-BUYLLA A. (1997) Cellular composition and three-dimensional organization of the subventricular germinal zone in the adult mammalian brain. J Neurosci 17:5046-5061.

DONKERVOORT S, SIDDIQUE T. 1993 Amyotrophic Lateral Sclerosis Overview. P.^Pp. in In GeneReviews, TDB R.A. PAGON, C.R. DOLAN, K. STEPHENS, AND M.P. ADAM, ed., Seattle (WA).

EDWARDS MA, YAMAMOTO M, CAVINESS VS, JR. (1990) Organization of radial glia and related cells in the developing murine CNS. An analysis based upon a new monoclonal antibody marker. Neuroscience 36:121-144.

EGGER B, GOLD KS, BRAND AH. (2011) Regulating the balance between symmetric and asymmetric stem cell division in the developing brain. Fly (Austin) 5:237-241

ELDRIDGE CF, BUNGE MB, BUNGE RP, WOOD PM. (1987) Differentiation of axon-related Schwann cells in vitro. I. Ascorbic acid regulates basal lamina assembly and myelin formation. J Cell Biol 105:1023-1034.

ESTEBAN MA, WANG T, QIN B, YANG J, QIN D, CAI J, LI W, WENG Z, CHEN J, NI S, CHEN K, LI Y, LIU X, XU J, ZHANG S, LI F, HE W, LABUDA $\mathrm{K}$, SONG $\mathrm{Y}$, PETERBAUER A, WOLBANK S, REDL $\mathrm{H}$, 
ZHONG M, CAI D, ZENG L, PEI D. (2010) Vitamin C enhances the generation of mouse and human induced pluripotent stem cells. Cell Stem Cell 6:71-79.

FAALAND CA, RACE JE, RICKEN G, WARNER FJ, WILLIAMS WJ, HOLTZMAN EJ. (1998) Molecular characterization of two novel transporters from human and mouse kidney and from LLC-PK1 cells reveals a novel conserved family that is homologous to bacterial and Aspergillus nucleobase transporters. Biochim Biophys Acta 1442:353-360.

FODE C, MA Q, CASAROSA S, ANG SL, ANDERSON DJ, GUILLEMOT F. (2000) A role for neural determination genes in specifying the dorsoventral identity of telencephalic neurons. Genes Dev 14:67-80.

FREEMAN MR. (2010) Specification and morphogenesis of astrocytes. Science 330:774-778.

GARCÍA MA, SALAZAR K, MILLÁN C, RODRÍGUEZ F, MONTECINOS H, CAPRILE T, SILVA C, CORTÉS C, REINICKE K, VERA JC, AGUAYO LG, OLATE J, MOLINA B, NUALART F. (2005) Sodium vitamin C cotransporter SVCT2 is expressed in hypothalamic glial cells. Glia 50:32-47.

GARCÍA-VERDUGO JM, DOETSCH F, WICHTERLE H, LIM DA ÁLVAREZ-BUYLLA A. (1998) Architecture and cell types of the adult subventricular zone: in search of the stem cells. J Neurobiol 36:234-248.

GEELEN JA, LANGMAN J. (1979) Ultrastructural observations on closure of the neural tube in the mouse. Anat Embryol (Berl) 156:73-88

GESS B, LOHMANN C, HALFTER H, YOUNG P. (2010) Sodium-dependent vitamin C transporter 2 (SVCT2) is necessary for the uptake of L-ascorbic acid into Schwann cells. Glia 58:287-299.

GESS B, ROHR D, FLEDRICH R, SEREDA MW, KLEFFNER I, HUMBERG A NOWITZKI J, STRECKER JK, HALFTER H, YOUNG P. (2011) Sodiumdependent vitamin $\mathrm{C}$ transporter 2 deficiency causes hypomyelination and extracellular matrix defects in the peripheral nervous system. J Neurosci 31:17180-17192.

GLEMBOTSKI CC. (1987) The role of ascorbic acid in the biosynthesis of the neuroendocrine peptides alpha-MSH and TRH. Ann N Y Acad Sci 498:54-62.

GODOY A, ORMAZÁBAL V, MORAGA-CID G, ZÚÑIGA FA, SOTOMAYOR P, BARRA V, VÁSQUEZ O, MONTECINOS V, MARDONES L, GUZMÁN C, VILLAGRÁN M, AGUAYO LG, ONATE SA, REYES AM, CÁRCAMO JG, RIVAS CI, VERA JC. (2007) Mechanistic insights and functional determinants of the transport cycle of the ascorbic acid transporter SVCT2. Activation by sodium and absolute dependence on bivalent cations. J Biol Chem 282:615-624.

GOTZ M, HUTTNER WB. (2005) The cell biology of neurogenesis. Nat Rev Mol Cell Biol 6:777-788.

GRADWOHL G, FODE C, GUILLEMOT F. (1996) Restricted expression of a novel murine atonal-related bHLH protein in undifferentiated neural precursors. Dev Biol 180:227-241.

GUILLEMOT F, LO LC, JOHNSON JE, AUERBACH A, ANDERSON DJ, JOYNER AL. (1993) Mammalian achaete-scute homolog 1 is required for the early development of olfactory and autonomic neurons. Cell 75:463476.

HARRISON FE, MAY JM. (2009) Vitamin C function in the brain: vital role of the ascorbate transporter SVCT2. Free Radic Biol Med 46:719-730.

HARTFUSS E, GALLI R, HEINS N, GOTZ M. (2001) Characterization of CNS precursor subtypes and radial glia. Dev Biol 229:15-30.

HAUBENSAK W, ATTARDO A, DENK W, HUTTNER WB. (2004) Neurons arise in the basal neuroepithelium of the early mammalian telencephalon: a major site of neurogenesis. Proc Natl Acad Sci U S A 101:3196-3201.

HORNING MG, NOWLIN J, BUTLER CM, LERTRATANANGKOON K, SOMMER K, HILL RM. (1975) Clinical applications of gas chromatograph/mass spectrometer/computer systems. Clin Chem 21:1282-1287.

HUTTNER WB, BRAND M. (1997) Asymmetric division and polarity of neuroepithelial cells. Curr Opin Neurobiol 7:29-39.

JACOBS FM, VAN ERP S, VAN DER LINDEN AJ, VON OERTHEL L, BURBACH JP, SMIDT MP. (2009) Pitx3 potentiates Nurr1 in dopamine neuron terminal differentiation through release of SMRT-mediated repression. Development 136:531-540.

JIANG J, MCMURTRY J, NIEDZWIECKI D, GOLDMAN SA. (1998) Insulinlike growth factor-1 is a radial cell-associated neurotrophin that promotes neuronal recruitment from the adult songbird edpendyma/ subependyma. J Neurobiol 36:1-15.

KAGEYAMA R, OHTSUKA T, HATAKEYAMA J, OHSAWA R. (2005) Roles of bHLH genes in neural stem cell differentiation. Exp Cell Res 306:343-348.

KARUMBAYARAM S, NOVITCH BG, PATTERSON M, UMBACH JA, RICHTER L, LINDGREN A, CONWAY AE, CLARK AT, GOLDMAN SA, PLATH K, WIEDAU-PAZOS M, KORNBLUM HI, LOWRY WE.
(2009) Directed differentiation of human-induced pluripotent stem cells generates active motor neurons. Stem Cells 27:806-811.

KAYA F, BELIN S, BOURGEOIS P, MICALEFF J, BLIN O, FONTES M. (2007) Ascorbic acid inhibits PMP22 expression by reducing cAMP levels. Neuromuscul Disord 17:248-253.

KIM H, KIM HY, CHOI MR, HWANG S, NAM KH, KIM HC, HAN JS, KIM KS, YOON HS, KIM SH. (2010) Dose-dependent efficacy of ALS-human mesenchymal stem cells transplantation into cisterna magna in SOD1G93A ALS mice. Neurosci Lett 468:190-194.

KRATZING CC, KELLY JD, KRATZING JE. (1985) Ascorbic acid in fetal rat brain. J Neurochem 44:1623-1624.

KRATZING CC, KELLY JD, OELRICHS BA. (1982) Ascorbic acid in neural tissues. J Neurochem 39:625-627.

KRIEGSTEIN A, ÁLVAREZ-BUYLLA A. (2009) The glial nature of embryonic and adult neural stem cells. Annu Rev Neurosci 32:149-184.

KRIKS S, SHIM JW, PIAO J, GANAT YM, WAKEMAN DR, XIE Z, CARRILLO-REID L, AUYEUNG G, ANTONACCI C, BUCH A, YANG L, BEAL MF, SURMEIER DJ, KORDOWER JH, TABAR V, STUDER L. (2011) Dopamine neurons derived from human ES cells efficiently engraft in animal models of Parkinson's disease. Nature 480:547-551.

LAMBERT MP, BARLOW AK, CHROMY BA, EDWARDS C, FREED R, LIOSATOS M, MORGAN TE, ROZOVSKY I, TROMMER B, VIOLA KL, WALS P, ZHANG C, FINCH CE, KRAFFT GA, KLEIN WL. (1998) Diffusible, nonfibrillar ligands derived from Abeta1-42 are potent central nervous system neurotoxins. Proc Natl Acad Sci U S A 95:6448-6453.

LEE DA, BEDONT JL, PAK T, WANG H, SONG J, MIRANDA-ANGULO A, TAKIAR V, CHARUBHUMI V, BALORDI F, TAKEBAYASHI $\mathrm{H}$, AJA S, FORD E, FISHELL G, BLACKSHAW S. (2012) Tanycytes of the hypothalamic median eminence form a diet-responsive neurogenic niche. Nat Neurosci 15:700-702.

LEE HG, PERRY G, MOREIRA PI, GARRETT MR, LIU Q, ZHU X, TAKEDA A, NUNOMURA A, SMITH MA. (2005) Tau phosphorylation in Alzheimer's disease: pathogen or protector? Trends Mol Med 11:164-169.

LEE JY, CHANG MY, PARK CH, KIM HY, KIM JH, SON H, LEE YS, LEE SH. (2003) Ascorbate-induced differentiation of embryonic cortical precursors into neurons and astrocytes. J Neurosci Res 73:156-165.

LENDAHL U, ZIMMERMAN LB, MCKAY RD. (1990) CNS stem cells express a new class of intermediate filament protein. Cell 60:585-595.

LEPORE AC, RAUCK B, DEJEA C, PARDO AC, RAO MS, ROTHSTEIN JD, MARAGAKIS NJ. (2008) Focal transplantation-based astrocyte replacement is neuroprotective in a model of motor neuron disease. Nat Neurosci 11:1294-1301.

LI QJ, TANG YM, LIU J, ZHOU DY, LI XP, XIAO SH, JIAN DX, XING YG. (2007) Treatment of Parkinson disease with C17.2 neural stem cells overexpressing NURR1 with a recombined republic-deficit adenovirus containing the NURR1 gene. Synapse 61:971-977.

LIU J, LAUDER JM. (1992) Serotonin promotes region-specific glial influences on cultured serotonin and dopamine neurons. Glia 5:306-317.

LUTSENKO EA, CARCAMO JM, GOLDE DW. (2004) A human sodiumdependent vitamin $C$ transporter 2 isoform acts as a dominant-negative inhibitor of ascorbic acid transport. Mol Cell Biol 24:3150-3156.

MA Q, KINTNER C, ANDERSON DJ. (1996) Identification of neurogenin, a vertebrate neuronal determination gene. Cell 87:43-52.

MA W, LIU QY, JUNG D, MANOS P, PANCRAZIO JJ, SCHAFFNER AE, BARKER JL, STENGER DA. (1998) Central neuronal synapse formation on micropatterned surfaces. Brain Res Dev Brain Res 111:231-243.

MALATESTA P, HACK MA, HARTFUSS E, KETTENMANN H, KLINKERT W, KIRCHHOFF F, GOTZ M. (2003) Neuronal or glial progeny: regional differences in radial glia fate. Neuron 37:751-764.

MALATESTA P, HARTFUSS E, GOTZ M. (2000) Isolation of radial glial cells by fluorescent-activated cell sorting reveals a neuronal lineage. Development 127:5253-5263.

MARUTLE A, OHMITSU M, NILBRATT M, GREIG NH, NORDBERG A, SUGAYA K. (2007) Modulation of human neural stem cell differentiation in Alzheimer (APP23) transgenic mice by phenserine. Proc Natl Acad Sci U S A 104:12506-12511.

MICALLEF J, ATTARIAN S, DUBOURG O, GONNAUD PM, HOGREL JY, STOJKOVIC T, BERNARD R, JOUVE E, PITEL S, VACHEROT F, REMEC JF, JOMIR L, AZABOU E, AL-MOUSSAWI M, LEFEBVRE MN ATTOLINI L, YAICI S, TANESSE D, FONTES M, POUGET J, BLIN O. (2009) Effect of ascorbic acid in patients with Charcot-Marie-Tooth disease type 1A: a multicentre, randomised, double-blind, placebocontrolled trial. Lancet Neurol 8:1103-1110.

MILBY K, OKE A, ADAMS RN. (1982) Detailed mapping of ascorbate distribution in rat brain. Neurosci Lett 28:169-174. 
MORGAN D, DIAMOND DM, GOTTSCHALL PE, UGEN KE, DICKEY C, HARDY J, DUFF K, JANTZEN P, DICARLO G, WILCOCK D, CONNOR K, HATCHER J, HOPE C, GORDON M, ARENDASH GW. (2000) A beta peptide vaccination prevents memory loss in an animal model of Alzheimer's disease. Nature 408:982-985.

MORRENS J, VAN DEN BROECK W, KEMPERMANN G. (2012) Glial cells in adult neurogenesis. Glia 60:159-174.

MORRISON SJ, PÉREZ SE, QIAO Z, VERDI JM, HICKS C, WEINMASTER G, ANDERSON DJ. (2000) Transient Notch activation initiates an irreversible switch from neurogenesis to gliogenesis by neural crest stem cells. Cell 101:499-510.

MUCKE L, MASLIAH E, YU GQ, MALLORY M, ROCKENSTEIN EM, TATSUNO G, HU K, KHOLODENKO D, JOHNSON-WOOD K, MCCONLOGUE L. (2000) High-level neuronal expression of abeta 1-42 in wild-type human amyloid protein precursor transgenic mice: synaptotoxicity without plaque formation. J Neurosci 20:4050-4058.

MURAD S, SIVARAJAH A, PINNELL SR. (1981) Regulation of prolyl and lysyl hydroxylase activities in cultured human skin fibroblasts by ascorbic acid. Biochem Biophys Res Commun 101:868-875.

NAKASHIMA K, TAKIZAWA T, OCHIAI W, YANAGISAWA M, HISATSUNE T, NAKAFUKU M, MIYAZONO K, KISHIMOTO T, KAGEYAMA R, TAGA T. (2001) BMP2-mediated alteration in the developmental pathway of fetal mouse brain cells from neurogenesis to astrocytogenesis. Proc Natl Acad Sci U S A 98:5868-5873.

NIETO M, SCHUURMANS C, BRITZ O, GUILLEMOT F. (2001) Neural bHLH genes control the neuronal versus glial fate decision in cortical progenitors. Neuron 29:401-413.

NISHIKIMI M, YAGI K. (1991) Molecular basis for the deficiency in humans of gulonolactone oxidase, a key enzyme for ascorbic acid biosynthesis. Am J Clin Nutr 54:1203S-1208S.

NOCTOR SC, FLINT AC, WEISSMAN TA, WONG WS, CLINTON BK, KRIEGSTEIN AR. (2002) Dividing precursor cells of the embryonic cortical ventricular zone have morphological and molecular characteristics of radial glia. J Neurosci 22:3161-3173.

NUALART FJ, RIVAS CI, MONTECINOS VP, GODOY AS, GUAIQUIL VH, GOLDE DW, VERA JC. (2003) Recycling of vitamin C by a bystander effect. J Biol Chem 278:10128-10133.

OHTSUKA M, FUKUMITSU H, FURUKAWA S. (2009) Neurotrophin-3 stimulates neurogenetic proliferation via the extracellular signalregulated kinase pathway. J Neurosci Res 87:301-306.

OKANO H, TEMPLE S. (2009) Cell types to order: temporal specification of CNS stem cells. Curr Opin Neurobiol 19:112-119.

OLSEN CL, BUNGE RP. (1986) Requisites for growth and myelination of urodele sensory neurons in tissue culture. J Exp Zool 238:373-384.

ORELLANA JA, SÁEZ PJ, CORTÉS-CAMPOS C, ELIZONDO RJ, SHOJI KF, CONTRERAS-DUARTE S, FIGUEROA V, VELARDE V, JIANG JX, NUALART F, SÁEZ JC, GARCÍA MA. (2012) Glucose increases intracellular free $\mathrm{Ca}(2+)$ in tanycytes via ATP released through connexin 43 hemichannels. Glia 60:53-68.

OTA M, ITO K. (2003) Induction of neurogenin-1 expression by sonic hedgehog: Its role in development of trigeminal sensory neurons. Dev Dyn 227:544-551.

PAPADEAS ST, KRAIG SE, O'BANION C, LEPORE AC, MARAGAKIS NJ. (2011) Astrocytes carrying the superoxide dismutase 1 (SOD1G93A) mutation induce wild-type motor neuron degeneration in vivo. Proc Natl Acad Sci U S A 108:17803-17808.

PASSAGE E, NORREEL JC, NOACK-FRAISSIGNES P, SANGUEDOLCE $\mathrm{V}$, PIZANT J, THIRION X, ROBAGLIA-SCHLUPP A, PELLISSIER JF, FONTES M. (2004) Ascorbic acid treatment corrects the phenotype of a mouse model of Charcot-Marie-Tooth disease. Nat Med 10:396-401.

PERRIER AL, TABAR V, BARBERI T, RUBIO ME, BRUSES J, TOPF N, HARRISON NL, STUDER L. (2004) Derivation of midbrain dopamine neurons from human embryonic stem cells. Proc Natl Acad Sci U S A 101:12543-12548.

PETERKOFSKY B. (1972) Regulation of collagen secretion by ascorbic acid in $3 \mathrm{~T} 3$ and chick embryo fibroblasts. Biochem Biophys Res Commun 49:1343-1350.

PETERKOFSKY B. (1991) Ascorbate requirement for hydroxylation and secretion of procollagen: relationship to inhibition of collagen synthesis in scurvy. Am J Clin Nutr 54:1135S-1140S.

PHILIPS T, ROBBERECHT W. (2011) Neuroinflammation in amyotrophic lateral sclerosis: role of glial activation in motor neuron disease. Lancet Neurol 10:253-263.

PRZEDBORSKI S, JACKSON-LEWIS V, DJALDETTI R, LIBERATORE G, VILA M, VUKOSAVIC S, ALMER G. (2000) The parkinsonian toxin MPTP: action and mechanism. Restor Neurol Neurosci 16:135-142.
OIAN X, SHEN Q, GODERIE SK, HE W, CAPELA A, DAVIS AA, TEMPLE S. (2000) Timing of CNS cell generation: a programmed sequence of neuron and glial cell production from isolated murine cortical stem cells. Neuron 28:69-80.

QIU S, LI L, WEEBER EJ, MAY JM. (2007) Ascorbate transport by primary cultured neurons and its role in neuronal function and protection against excitotoxicity. J Neurosci Res 85:1046-1056.

RAY HJ, NISWANDER L. (2012) Mechanisms of tissue fusion during development. Development 139:1701-1711.

REBEC GV, PIERCE RC. (1994) A vitamin as neuromodulator: ascorbate release into the extracellular fluid of the brain regulates dopaminergic and glutamatergic transmission. Prog Neurobiol 43:537-565.

REBOUCHE CJ. (1991) Ascorbic acid and carnitine biosynthesis. Am J Clin Nutr 54:1147S-1152S.

RENTON AE, MAJOUNIE E, WAITE A, SIMON-SÁNCHEZ J, ROLLINSON $S$, GIBBS JR, SCHYMICK JC, LAAKSOVIRTA H, VAN SWIETEN JC, MYLLYKANGAS L, KALIMO H, PAETAU A, ABRAMZON Y, REMES AM, KAGANOVICH A, SCHOLZ SW, DUCKWORTH J, DING J, HARMER DW, HERNÁNDEZ DG, JOHNSON JO, MOK K, RYTEN M, TRABZUNI D, GUERREIRO RJ, ORRELL RW, NEAL J, MURRAY A, PEARSON J, JANSEN IE, SONDERVAN D, SEELAAR $\mathrm{H}$, BLAKE D, YOUNG K, HALLIWELL N, CALLISTER JB, TOULSON G, RICHARDSON A, GERHARD A, SNOWDEN J, MANN D, NEARY D, NALLS MA, PEURALINNA T, JANSSON L, ISOVIITA VM, KAIVORINNE AL, HOLTTA-VUORI M, IKONEN E, SULKAVA $\mathrm{R}$, BENATAR M, WUU J, CHIO A, RESTAGNO G, BORGHERO G, SABATELLI M, HECKERMAN D, ROGAEVA E, ZINMAN L, ROTHSTEIN JD, SENDTNER M, DREPPER C, EICHLER EE, ALKAN C, ABDULLAEV Z, PACK SD, DUTRA A, PAK E, HARDY J, SINGLETON A, WILLIAMS NM, HEUTINK P, PICKERING-BROWN S, MORRIS HR, TIENARI PJ, TRAYNOR BJ. (2011) A hexanucleotide repeat expansion in C9ORF72 is the cause of chromosome 9p21-linked ALS-FTD. Neuron $72: 257-268$.

RICE ME. (2000) Ascorbate regulation and its neuroprotective role in the brain. Trends Neurosci 23:209-216.

RUMSEY SC, DARUWALA R, AL-HASANI H, ZARNOWSKI MJ, SIMPSON IA, LEVINE M. (2000) Dehydroascorbic acid transport by GLUT4 in Xenopus oocytes and isolated rat adipocytes. J Biol Chem 275:2824628253.

RUMSEY SC, KWON O, XU GW, BURANT CF, SIMPSON I, LEVINE M. (1997) Glucose transporter isoforms GLUT1 and GLUT3 transport dehydroascorbic acid. J Biol Chem 272:18982-18989.

SANAI N, TRAMONTIN AD, QUINONES-HINOJOSA A, BARBARO NM, GUPTA N, KUNWAR S, LAWTON MT, MCDERMOTT MW, PARSA AT, MANUEL-GARCÍA VERDUGO J, BERGER MS, ÁLVAREZ-BUYLLA A. (2004) Unique astrocyte ribbon in adult human brain contains neural stem cells but lacks chain migration. Nature 427:740-744.

SANDSTROM MI, REBEC GV. (2007) Extracellular ascorbate modulates glutamate dynamics: role of behavioral activation. BMC Neurosci 8:32.

SAVINI I, ROSSI A, PIERRO C, AVIGLIANO L, CATANI MV. (2008) SVCT1 and SVCT2: key proteins for vitamin C uptake. Amino Acids 34:347-355.

SOMMER L, MA Q, ANDERSON DJ. (1996) neurogenins, a novel family of atonal-related bHLH transcription factors, are putative mammalian neuronal determination genes that reveal progenitor cell heterogeneity in the developing CNS and PNS. Mol Cell Neurosci 8:221-241.

SONG HW, KUMAR BK, KIM SH, JEON YH, LEE YA, LEE WT, PARK KA, LEE JE. (2011) Agmatine enhances neurogenesis by increasing ERK1/2 expression, and suppresses astrogenesis by decreasing BMP 2,4 and SMAD 1,5,8 expression in subventricular zone neural stem cells. Life Sci 89:439-449.

SOTIRIOU S, GISPERT S, CHENG J, WANG Y, CHEN A, HOOGSTRATENMILLER S, MILLER GF, KWON O, LEVINE M, GUTTENTAG SH, NUSSBAUM RL. (2002) Ascorbic-acid transporter Slc23a1 is essential for vitamin $C$ transport into the brain and for perinatal survival. Nat Med 8:514-517

SUBRAMANIAN VS, MARCHANT JS, REIDLING JC, SAID HM. (2008) $\mathrm{N}$-Glycosylation is required for Na+-dependent vitamin $\mathrm{C}$ transporter functionality. Biochem Biophys Res Commun 374:123-127.

SUN Y, NADAL-VICENS M, MISONO S, LIN MZ, ZUBIAGA A, HUA X, FAN G, GREENBERG ME. (2001) Neurogenin promotes neurogenesis and inhibits glial differentiation by independent mechanisms. Cell 104:365-376.

TABAR V, TOMISHIMA M, PANAGIOTAKOS G, WAKAYAMA S, MENON J, CHAN B, MIZUTANI E, AL-SHAMY G, OHTA H, WAKAYAMA T, STUDER L. (2008) Therapeutic cloning in individual parkinsonian mice. Nat Med 14:379-381. 
TAVERNA E, HUTTNER WB. (2010) Neural progenitor nuclei IN motion. Neuron 67:906-914

TAWK M, ARAYA C, LYONS DA, REUGELS AM, GIRDLER GC, BAYLEY PR, HYDE DR, TADA M, CLARKE JD. (2007) A mirror-symmetric cell division that orchestrates neuroepithelial morphogenesis. Nature 446:797-800.

TEMPLE S. (2001) The development of neural stem cells. Nature 414:112-117.

THISSE B, THISSE C. (2005) Functions and regulations of fibroblast growth factor signaling during embryonic development. Dev Biol 287:390-402.

TRAMONTIN AD, GARCÍA-VERDUGO JM, LIM DA, ÁLVAREZ-BUYLLA A. (2003) Postnatal development of radial glia and the ventricular zone (VZ): a continuum of the neural stem cell compartment. Cereb Cortex 13:580-587.

TRAUB R, MITSUMOTO H, ROWLAND LP. (2011) Research advances in amyotrophic lateral sclerosis, 2009 to 2010. Curr Neurol Neurosci Rep 11:67-77.

TROJANOWSKI JQ, LEE VM. (1998) Aggregation of neurofilament and alpha-synuclein proteins in Lewy bodies: implications for the pathogenesis of Parkinson disease and Lewy body dementia. Arch Neurol 55:151-152.

TSUKAGUCHI H, TOKUI T, MACKENZIE B, BERGER UV, CHEN XZ, WANG Y, BRUBAKER RF, HEDIGER MA. (1999) A family of mammalian Na+-dependent L-ascorbic acid transporters. Nature 399:70-75.

TVEDEN-NYBORG P, JOHANSEN LK, RAIDA Z, VILLUMSEN CK, LARSEN JO, LYKKESFELDT J. (2009) Vitamin C deficiency in early postnatal life impairs spatial memory and reduces the number of hippocampal neurons in guinea pigs. Am J Clin Nutr 90:540-546.

VAN DEN BOSCH L, VAN DAMME P, BOGAERT E, ROBBERECHT W. (2006) The role of excitotoxicity in the pathogenesis of amyotrophic lateral sclerosis. Biochim Biophys Acta 1762:1068-1082.

VERA JC, RIVAS CI, FISCHBARG J, GOLDE DW. (1993) Mammalian facilitative hexose transporters mediate the transport of dehydroascorbic acid. Nature 364:79-82.

VERHAMME C, DE HAAN RJ, VERMEULEN M, BAAS F, DE VISSER M, VAN SCHAIK IN. (2009) Oral high dose ascorbic acid treatment for one year in young CMT1A patients: a randomised, double-blind, placebocontrolled phase II trial. BMC Med 7:70.
VON BOHLEN UND HALBACH O. (2011) Immunohistological markers for proliferative events, gliogenesis, and neurogenesis within the adult hippocampus. Cell Tissue Res 345:1-19.

WANG H, DUTTA B, HUANG W, DEVOE LD, LEIBACH FH, GANAPATHY V, PRASAD PD. (1999) Human $\mathrm{Na}(+)$-dependent vitamin $\mathrm{C}$ transporter 1 (hSVCT1): primary structure, functional characteristics and evidence for a non-functional splice variant. Biochim Biophys Acta 1461:1-9.

WANG T, CHEN K, ZENG X, YANG J, WU Y, SHI X, QIN B, ZENG L, ESTEBAN MA, PAN G, PEI D. (2011) The histone demethylases Jhdm $1 \mathrm{a} / 1 \mathrm{~b}$ enhance somatic cell reprogramming in a vitamin-Cdependent manner. Cell Stem Cell 9:575-587.

WAYNER DD, BURTON GW, INGOLD KU. (1986) The antioxidant efficiency of vitamin C is concentration-dependent. Biochim Biophys Acta 884:119-123.

WILSON JX. (1990) Regulation of ascorbic acid concentration in embryonic chick brain. Dev Biol 139:292-298.

WINKLHOFER KF, HAASS C. (2010) Mitochondrial dysfunction in Parkinson's disease. Biochim Biophys Acta 1802:29-44.

WOODRUFF-PAK DS. (2008) Animal models of Alzheimer's disease: therapeutic implications. J Alzheimers Dis 15:507-521.

YAMANAKA K, CHUN SJ, BOILLEE S, FUJIMORI-TONOU N, YAMASHITA H, GUTMANN DH, TAKAHASHI R, MISAWA H, CLEVELAND DW. (2008) Astrocytes as determinants of disease progression in inherited amyotrophic lateral sclerosis. Nat Neurosci 11:251-253.

YAMASAKI M, YAMADA K, FURUYA S, MITOMA J, HIRABAYASHI Y, WATANABE M. (2001) 3-Phosphoglycerate dehydrogenase, a key enzyme for l-serine biosynthesis, is preferentially expressed in the radial glia/ astrocyte lineage and olfactory ensheathing glia in the mouse brain. J Neurosci 21:7691-7704.

YAN J, STUDER L, MCKAY RD. (2001) Ascorbic acid increases the yield of dopaminergic neurons derived from basic fibroblast growth factor expanded mesencephalic precursors. J Neurochem 76:307-311.

YANG R, CHEN J, DENG Z, LIU X. (2001) [Effect of vitamin E on morphological variation of retinal ganglion cells after microwave radiation]. Wei Sheng Yan Jiu 30:31-33.

ZHOU ZD, KUMARI U, XIAO ZC, TAN EK. (2010) Notch as a molecular switch in neural stem cells. IUBMB Life 62:618-623. 